\title{
Medicinal Plants: Guests and Hosts in the Heterologous Expression of High-Value Products
}

\begin{abstract}
Author
Nikolay Vasilev ${ }^{\mathbb{D}}$

Affiliation

TU Dortmund University, Biochemical and Chemical Engineering, Technical Biochemistry, Dortmund, Germany
\end{abstract}

\section{Key words}

recombinant DNA technology, secondary plant metabolites, therapeutic proteins, heterologous expression, metabolic engineering, synthetic biology

\author{
received \\ May 16, 2021 \\ accepted after revision \\ July 30, 2021 \\ published online \\ September 14, 2021 \\ Bibliography \\ Planta Med 2022; 88: 1175-1189 \\ DOI 10.1055/a-1576-4148 \\ ISSN 0032-0943 \\ (c) 2021. Thieme. All rights reserved. \\ Georg Thieme Verlag KG, Rüdigerstraße 14, \\ 70469 Stuttgart, Germany \\ Correspondence \\ Dr. Nikolay Vasilev \\ TU Dortmund University, Biochemical and \\ Chemical Engineering \\ Emil-Figge-Strasse 66, 44227 Dortmund, Germany \\ Phone: + 492317555115 , Fax: + 492317557382 \\ nikolay.vasilev@tu-dortmund.de
}

\begin{abstract}
Medicinal plants play an important dual role in the context of the heterologous expression of high-value pharmaceutical products. On the one hand, the classical biochemical and modern omics approaches allowed for the discovery of various genes encoding biosynthetic pathways in medicinal plants. Recombinant DNA technology enabled introducing these genes and regulatory elements into host organisms and enhancing the heterologous production of the corresponding secondary metabolites. On the other hand, the transient expression of foreign DNA in plants facilitated the production of numerous proteins of pharmaceutical importance. This review summarizes several success stories of the engineering of plant metabolic pathways in heterologous hosts. Likewise, a few examples of recombinant protein expression in plants for therapeutic purposes are also highlighted. Therefore, the importance of medicinal plants has grown immensely as sources for valuable products of low and high molecular weight. The next step ahead for bioengineering is to achieve more success stories of industrial-scale production of secondary plant metabolites in microbial systems and to fully exploit plant cell factories' commercial potential for recombinant proteins.
\end{abstract}

\section{Introduction}

Plants have been utilized as remedies since antiquity. The earliest documented record of using plants as medicines dates back to the culture of the Neanderthal people ( 60000 BC). Some of the ancient knowledge of medicinal plants reached us owing to the written documents or books like Ebers Papyrus (1500 BC), History of Plants (Theophrastus; 300 BC), De Materia Medica (Dioscorides; $100 \mathrm{AD}$ ), and Canon medicinae (Avicenna; 1025 AD) [1].

Many of the current drugs originate from natural products [2]. Today, about $80 \%$ of the population in developing countries rely on herbal medicinal products as a primary source of healthcare and traditional medical practice [3]. The survey by Newman and Cragg [4] revealed that out of the 1602 new chemical entities approved as drugs between 1981 and 2019, 751 were with natural origin (i. e., "unaltered natural products, botanical drugs [defined mixtures], natural product derivatives [or mimics] or made by total synthesis but the pharmacophore is from a natural product").

Native plants are among the most common sources of bioactive natural products ( $\bullet$ Table 1 ). For instance, 12000 Taxus brevifolia trees were chopped down to provide the $2 \mathrm{~kg}$ substance necessary for the studies at the beginning of the Taxol study [5]. Therefore, a sustainable balance needs to be established between exploiting the plants as resources for natural products and environmental protection. Galantamine content reaches $0.1-0.2 \%$ based on the dry weight of daffodil bulbs. Although the total chemical synthesis is possible, galantamine is also produced currently from plants because its synthetic route is difficult and expensive. Furthermore, the last stages of the galantamine synthesis have to be executed carefully to avoid any health risk due to the sensitization potential of narwedine [6]. In another recent study, the price of ginsenosides obtained from Panax plants was rela- 
- Table 1 Plant-derived natural products of importance for the pharmaceutical industry (adapted from [2]).

\begin{tabular}{|c|c|c|c|c|}
\hline Compound & Plant species & Need (to/y) & Price USD\$/kg & Reference \\
\hline Artemisinin & A. annua & $50-60$ & 100 & {$[109,110]$} \\
\hline Paclitaxel & T. brevifolia & 0.5 & $26000-38000$ & [2] \\
\hline Docetaxol & T. brevifolia & 0.3 & $8200-43200$ & [2] \\
\hline Resveratrol & V. vinifera & 10000 & 600 & {$[111]$} \\
\hline Ajmalicine & R. serpentina & 0.3 & 1500 & {$[112]$} \\
\hline Anthocyanins & V. vinifera & 2.0 & 2000 & {$[2,113]$} \\
\hline Vincristine & V. minor & 0.8 & 350000 & {$[2,113]$} \\
\hline Colchicine & C. autumnale & 5.0 & 6000 & {$[2,113]$} \\
\hline \multirow[t]{4}{*}{ Galantamine } & G. nivalis & $34^{*}$ & 50000 & \multirow[t]{4}{*}[6,114-116]{} \\
\hline & N. pseudonarcissus & & & \\
\hline & L. aestivum & & & \\
\hline & P. maritimum & & & \\
\hline Ginsenosides & P. ginseng & $1500 * *$ & 41000 & {$[7,117]$} \\
\hline
\end{tabular}

tively more expensive (25-57 USD/mg) in comparison to the cost of yeast-produced ginsenosides (0.5-25 USD/mg) [7]. Numerous natural products are also derived from plant foods and have additional health benefits beyond their basic nutritional value, thus preventing a wide range of chronic diseases [8]. The increased pharmaceutical and nutraceutical demand for valuable plant natural products, in general, has propelled the advancement of alternative biomanufacturing solutions based on metabolic engineering and synthetic biology [9].

Plants have been used today to produce both low and high molecular weight compounds of medicinal importance through DNA recombinant technology. As a result, the experimental workflow takes different steps depending on whether low or high molecular substances need to be produced. However, the overall cellular engineering process is based on design, build, test, and learn iterations, named the DBTL cycle [10].

The literature search strategy employed in this review comprises the recent developments of heterologous expression related to medicinal plants. However, specific details concerning plant biosynthesis of secondary metabolites or the production of recombinant proteins in plants are not included in this survey due to space limitations. Therefore, the reader is also referred to several interesting reviews on the plant secondary metabolites [1119 ] and the emerging field of molecular farming [20-22], respectively.

The first part of this review is focused on the production of small molecule compounds, and the second part centers on therapeutic proteins. The exemplary cases, for which most steps of the biosynthesis are already known, have been selected for the first part. This knowledge about the genes of interest encoding a partial or entire metabolic pathway in plants may also favor transferring the target metabolite production into a host organism and triggering potential industrial application. Several selected stories are included in the second part, showing the successful expression of recombinant proteins in plants. This review highlights the growing potential of medicinal plants for the biomanufacturing of high-value pharmaceutical products.

\section{Approaches for Gene Candidate Discovery in Plant Secondary Metabolism}

The metabolic reconstruction process goes through successive steps: gene discovery, host engineering, and pathway engineering $(\triangleright$ Fig. 1). Therefore, the discovery of gene candidates is the first committed step in the manipulation of biosynthetic pathways.

Classical biochemical and recent integrative approaches based on omics technologies (genomics, transcriptomics, proteomics, and metabolomics) have contributed to identifying promising candidate genes that belong to plant metabolic pathways of pharmaceutical significance.

The classical (reductionist) approach involves isolation and purification of an unknown enzyme, followed by a protein-mass spectrometric analysis, screening of cDNA libraries to identify the corresponding gene, and functional assay with the metabolite of interest at the end. For example, such a traditional approach was applied for cloning and characterization of norcoclaurine synthase, an enzyme catalyzing the initial step in benzylisoquinoline alkaloid (BIA) biosynthesis [23]. Degenerate primers were designed based on peptide sequences from the purified native norcoclaurine synthase (NCS). Next, the target nucleotide sequence was amplified by polymerase chain reaction using the aforementioned primers and a full-length cDNA isolated from a Thalictrum flavum cell culture as a template. The NCS enzyme is responsible 


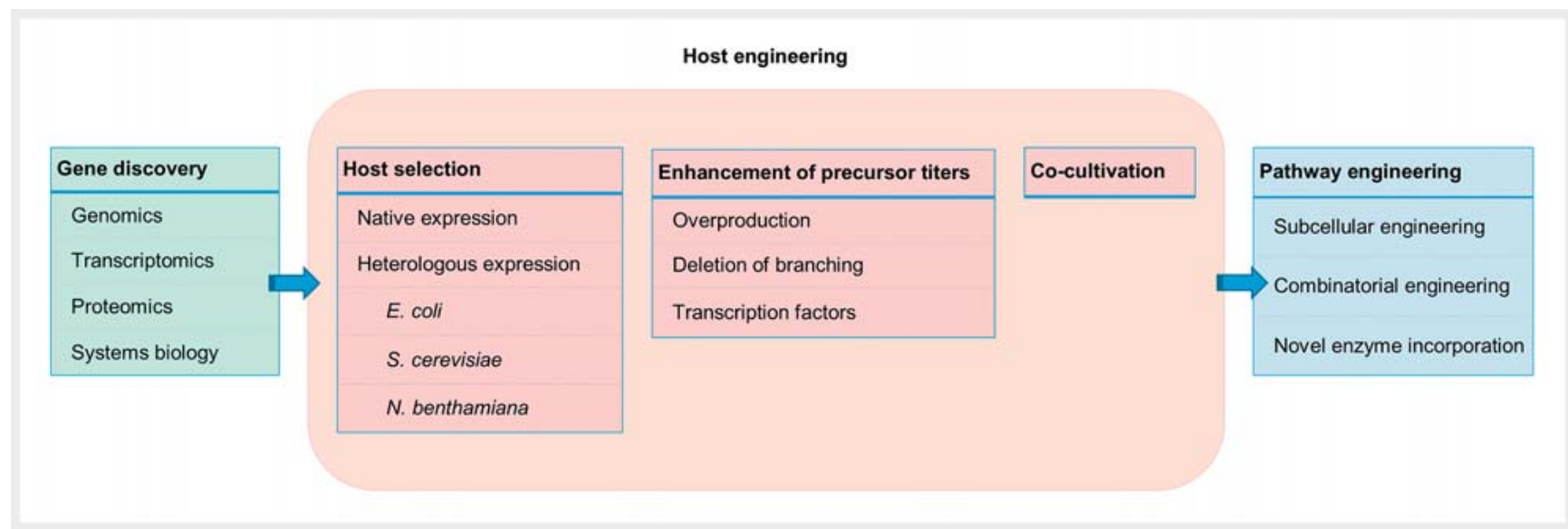

- Fig. 1 Common steps and features of metabolic engineering.

for the condensation of dopamine and 4-hydroxyphenylacetaldehyde to (S)-norcoclaurine from which all BIAs are derived.

The reduced sequencing costs and bioinformatics tools advancements led to the increased quantity of whole-genome sequences of medicinal plants in recent years [24].

Genome-wide association studies (GWAS) are a highly effective means of gene discovery in model plants and, together with expression quantitative trait loci (eQTLs), may explain a substantial fraction of phenotypic variation [25]. The most significant agronomic traits (i.e., grain size [weight], grain number, cold/salt tolerance, disease resistance, etc.) are controlled by multiple genes (namely, QTLs) and are strongly dependent on the environment [26]. GWAS were performed for 14 agronomic traits in Oryza sativa, which led to the detection of loci that explain $~ 36 \%$ of the phenotypic variance. Furthermore, 6 loci were closely related to previously known genes. This study shows the power of the next generation of genome sequencing and GWAS for dissecting complex traits [27]. Metabolic gene clusters are a common hallmark in microbial genomes. Such functional gene clusters are also occasionally found in plant genomes. One example of this gene cluster phenomenon is the discovery of genes that encode the biosynthesis of monoterpenes and diterpenes in Solanum lycopersicum [28]. Notably, high-resolution co-expression analyses based on genome sequencing revealed a coordinated biosynthesis of 3 distinct clusters within the major components of the monoterpene-derived indole alkaloid (MIA) pathway in Catharanthus roseus [29]. Hence, genomic sequences mining is a valuable tool for identifying metabolic gene clusters and, thus, for a partial or entire biosynthetic pathway [24].

Transcriptomics or global transcriptome profiling has modernized the field of phytochemistry [30]. RNA-seq-based transcriptome analysis provides valuable information about the active metabolic processes. Unlike microarray analysis, it does not require preliminary genomic information, which is also of key importance for the functional characterization of non-model plants. The appropriate statistical method may also lead to the identification of candidate genes from the target biosynthetic pathway. RNA-seq-based transcriptome analysis, especially in combination with metabolite profiling data, is a powerful tool for gene discov- ery. As an example, this approach enabled the detection of a locus with 10 clustered genes from the noscapine biosynthesis and virus-induced gene silencing validated the gene functions in the HN1 locus [31].

Proteomics can also facilitate gene discovery in biosynthetic pathways. Furthermore, it can contribute to the correct annotations of plant genomes. One example is the identification of the 4 enzymes in the secologanin pathway of $C$. roseus by using an integrated transcriptomics and proteomics approach. The whole strictosidine pathway was successfully reconstructed in a single $N$. benthamiana organ, despite its localization in various cell types like internal phloem-associated parenchyma or epidermis [32]. The screening of the pathogenesis-related 10 protein family, whose representatives are abundant in opium poppy latex, led to the discovery of neopinone isomerase, an important step in the biosynthesis of opiate alkaloids that was hypothesized in the past to be spontaneous [33].

Metabolomics is the principal tool for the unraveling of secondary metabolism in many plant families. Plant metabolomics is a complex methodology that investigates the global spectrum of natural compounds of plant origin with a molecular weight of less than 1000 Da, which are collectively named "metabolome" [34]. None of the genomics, transcriptomics, or proteomics can render any structural information about metabolic analytes. Several instrumentation or technological advancements are responsible for the key role of metabolomics in the gene discovery process of plant biosynthetic pathways; these include increased sensitivity, improved mass resolution, high-throughput automation, development of bioinformatics tools, and specialized online metabolite databases. Despite this progress, with metabolomics, it is not possible to measure the entire metabolome of a plant organism with a single analytical technique, unlike genomics and transcriptomics. However, this obstacle can be overcome by combining different separation techniques (gas chromatography, high-pressure liquid chromatography, and capillary electrophoresis) and detection systems (mass spectrometers, NMR, UV/VIS absorbance, fluorescence, IR absorbance).

The data from genomics, transcriptomics, proteomics, and metabolomics studies can also be integrated to obtain a global 


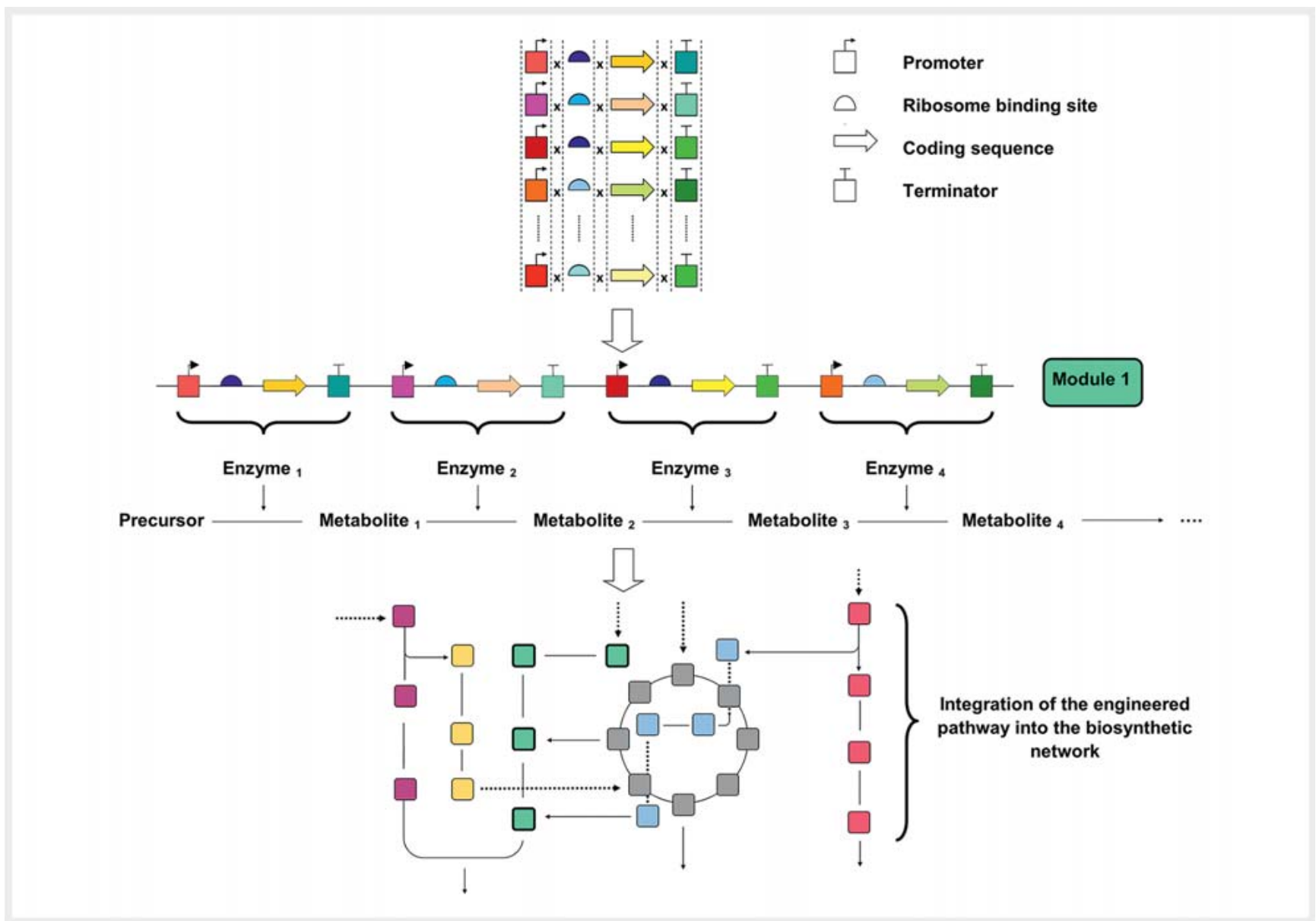

- Fig. 2 A schematic representation of the role of synthetic biology tools in metabolic engineering.

view of the response in a biological system. However, this systems biology approach encounters great technical challenges like scaling, noise removal, sensitivity, resolution, experimental design suitability, etc. [24]. Therefore, transcriptome-metabolome or metabolome-proteome integrations have been utilized more frequently for gene discovery in plant secondary metabolism.

\section{Strategies for Reconstruction of Plant Biosynthetic Pathways}

Synthetic biology is a future technology that may help preserve the environment through the sustainable production of natural plant products. While synthetic biology provides elements like promoters, coding sequences, terminators, transcriptional factors, binding sequences, etc., metabolic engineering uses all this information toward the optimized biosynthesis of the target metabolite [35]. Therefore, synthetic biology can significantly support metabolic engineering with its tools [36]. The synthetic biology approach frequently relies on the combination of components from diverse sources or species ( $\vee$ Fig. 2 ). This method redirects the biochemical resources of the organism to allow the efficient heterologous expression of the target metabolite(s).
The reconstitution of any plant biosynthetic pathway includes several key aspects for consideration. Once the target genes are discovered using classical or modern omics tools, the next step in any engineering strategy is identifying a suitable host organism. Several factors are important for selecting a host system: availability of techniques for cloning and culturing, suitability of a precursor pool, ease of cloning and culturing, suitability for an industrial scale-up application, etc. A first host option for producing valuable natural products with a plant origin potentially comprises plant cells or organisms, in which plant-specific subcellular compartments, substrate pools, protein processing, cofactors supply, and transcription regulation are probably conserved. Genetic modifications of plants are extremely difficult compared to microorganisms, which are often to prefer [37].

The heterologous hosts for the reconstitution of plant secondary metabolic pathways are recognized as a convenient and inexpensive alternative to the native producer. There are 3 major heterologous systems for accommodating plant metabolism: Escherichia coli, Saccharomyces cerevisiae, and Nicotiana benthamiana. E. coli is a well-characterized expression system with a shorter doubling period (3-4 times) than S. cerevisiae. However, some plant enzymes, such as cytochrome P450s, are transmembrane proteins, which can be problematic for prokaryotic hosts like E. coli. S. cerevisiae has several advantages: efficient homologous 
recombination rates and cellular organelles as a eukaryotic microorganism and can express cytochrome P450s. N. benthamiana is amenable to transient and stable transformation and can be applied to express a lengthy biosynthetic pathway due to its genestacking feature [38].

The subsequent step after selecting a host organism is to increase the pool of biosynthetic precursors to better produce the molecules of interest. The enhanced substrate titers can be achieved by the overproduction of precursor flux, downregulation of undesired side pathways, or manipulation of transcription factors expression. Modifications in the central yeast metabolism increased the supply of the BIA precursor tyrosine, resulting in a 60fold enhancement in the production of the early benzylisoquinoline precursors. The next engineering steps led to the accumulation of the key intermediate reticuline. These reconstructed reticuline strains may serve as a production platform for the biosynthesis of various natural and novel BIAs [39]. In another study dedicated to strictosidine, a common precursor in the monoterpene indole alkaloids metabolism, 3 yeast genes were deleted to diminish the flux feeding of competing biosynthetic branches [40]. Transcription factors regulate the gene expression of entire metabolic pathways and deliver effective tools for engineering high metabolites levels. Two snapdragon transcription factors were overexpressed in tomatoes, and as a result, the fruit of the plants accumulated anthocyanins close to the concentrations in blackberries and blueberries [41].

Co-cultivation is an interesting host engineering strategy for the biosynthesis of a wide range of plant metabolites. For instance, reticuline, an important constituent in BIAs biosynthesis, was produced first in E. coli cells. Next, several BIAs were synthesized from reticuline in S. cerevisiae cells as some plant enzymes are not expressed properly in bacteria. Such combined systems can decrease the metabolic burden in the host from the heterologous pathway and are beneficial for the expression of plant enzymes localized in cytosol and the endoplasmic reticulum (ER) [42].

Once all enzymes are identified, combined, and introduced into the heterologous host, the multistep pathway should be validated. The transition to a functional biosynthetic route in a heterologous host is a challenging process. The reduced activity of a heterologous enzyme may be due to one of the following reasons: improper folding of the enzyme, misprocessing of posttranslational modifications, suboptimal $\mathrm{pH}$, product feedback inhibition, etc. Subcellular engineering is one possible solution that can contribute to the proper intracellular localization of the enzyme, favorable $\mathrm{pH}$ and substrate conditions, etc. [37]. A new biosynthetic branch to neopine and neomorphine was found in an engineered yeast strain, carrying genes for opiates biosynthesis. This alternative route redirected pathway flux from morphine and other target metabolites. The main reason for the branching from morphine to nontarget neomorphine was the intermediate enzymatic step between thebaine 6-O-demethylase (T6ODM) and codeinone reductase (COR). Therefore, COR was targeted in the ER to allow a longer time for the spontaneous conversion of neopinone to codeinone and to enhance specificity for morphine compared to neomorphine biosynthesis [43]. The pathway manipulation by applying a combinatorial biosynthesis approach afforded novel compounds that are not found in the host, P. somniferum. Specifi- cally, CYP82Y1 yielded 1-hydroxycanadine instead of the common product 1-hydroxy- $\mathrm{N}$-methylcanadine when the preceding $\mathrm{N}$ methyltransferase is not present.

Similarly, swapping of CYP82Y1 with CYP82X2 in the native cascade led to the biosynthesis of $\mathrm{N}$-methylophiocarpine, an isomer of the native 1-hydroxy-N-methylcanadine [44]. Another study shows how unnatural compounds can be synthesized through novel enzyme integration into the native plant biosynthesis. A chlorination biosynthetic pathway from soil bacteria was inserted into $C$. roseus, yielding chlorinated tryptophan, which was then transferred into monoterpene indole alkaloid metabolism to produce chlorinated alkaloids [45].

\section{Engineering of Plant Secondary Metabolic Pathways}

The success in metabolic reconstruction depends largely on the thorough knowledge of the plant biosynthetic pathways. Therefore, genetic manipulations are successful mainly for secondary metabolic pathways with elucidated steps [24]. - Table 2 summarizes several exemplary natural products with their heterologous expression titers in yeast. This section presents examples of engineered plant metabolic pathways that are also heterologously expressed in microbial systems.

\section{Benzoisoquinoline Alkaloids}

The BIAs are a large group of biologically active compounds that attracted much attention to their pharmaceutical relevance and the development of microbial-based production systems. Moreover, most of the biosynthetic steps in the BIAs metabolism are unraveled so far. In one of the earliest studies on the reconstruction of a BIA pathway, transgenic $E$. coli cells, expressing a combination of 5 microbial and plant enzymes, produced (S)-reticuline from dopamine with a final yield of $55 \mathrm{mg} / \mathrm{L}$ within $1 \mathrm{~h}$. Several types of BIAs, including magnoflorine $(7.2 \mathrm{mg} / \mathrm{L})$ and scoulerine $(8.3 \mathrm{mg} / \mathrm{L})$, were synthesized from reticuline in the second step by using $S$. cerevisiae cells because several plant enzymes were not properly expressed in bacteria [42]. Yeast cells were engineered to produce reticuline and downstream BIA metabolites from the common substrate norlaudanosoline. The reticuline yields varied from $\approx 10$ to $150 \mathrm{mg} / \mathrm{L}$ depending on the enzyme combination. The yeast strains were also engineered to synthesize BIA metabolites along 2 of the major branches from reticuline: the sanguinarine and berberine branch and the morphinan branch [46]. Moreover, the E. coli fermentation system was constructed to yield (S)-reticuline at levels of $46 \mathrm{mg} / \mathrm{L}$ from simple carbon sources like glucose and glycerol without additional substrates $[47,48]$.

S. cerevisiae strains were engineered with genes from $P$. somniferum and Pseudomonas putida M10 to yield naturally occurring and semisynthetic opioids from the final steps of opiate biosynthesis. The fermentation production resulted in $131 \mathrm{mg} / \mathrm{L}$ total opioid levels. The development of this production platform is an important step toward sustainable opioid biomanufacturing in yeast [43]. In another study, gene discovery from opium poppy root and stem transcriptomes led to the reconstitution of a 10 - 
- Table 2 Heterologous titers of selected plant natural products (adapted from [2]).

\begin{tabular}{l|l|l|l|}
\hline Compound & Host organism & Titer & Reference \\
\hline \multirow{2}{*}{ Resveratrol } & E. coli & $1.4 \mathrm{~g} / \mathrm{L}$ & {$[111]$} \\
\hline & S. cerevisiae & $5 \mathrm{~g} / \mathrm{L}$ & {$[2]$} \\
\hline Vanillin & S. cerevisiae & $45 \mathrm{mg} / \mathrm{L}$ & {$[118,119]$} \\
\hline Naringenin & S. cerevisiae & $474 \mathrm{mg} / \mathrm{L}$ & {$[120]$} \\
\hline $\begin{array}{l}\text { Dihydroartesimic } \\
\text { acid }\end{array}$ & S. cerevisiae & $100 \mathrm{mg} / \mathrm{L}$ & {$[121]$} \\
\hline Artemsinic acid & $\begin{array}{l}\text { S. cerevisiae } \\
\text { (+ semi- } \\
\text { synthesis) }\end{array}$ & $25 \mathrm{~g} / \mathrm{L}$ & {$[122]$} \\
\hline Morphine & S. cerevisiae & $131 \mathrm{mg} / \mathrm{mL}$ & {$[43]$} \\
\hline THCA & S. cerevisiae & $2.3 \mathrm{mg} / \mathrm{L}$ & {$[62]$} \\
\hline CBDA & S. cerevisiae & $4.2 \mu \mathrm{g} / \mathrm{L}$ & {$[62]$} \\
\hline Ginsenoside Rh2 & S. cerevisiae & $2.25 \mathrm{~g} / \mathrm{L}$ & {$[66]$}
\end{tabular}

gene BIA cascade in yeast to yield dihydrosanguinarine and sanguinarine from the commercial substrate $(R, S)$-norlaudanosoline [49].

An enzyme-coupled biosensor for L-3,4-dihydroxyphenylalanine (L-DOPA) was developed to facilitate the finding of an active tyrosine hydroxylase in yeast (L-DOPA). Using this sensor and subsequent PCR mutagenesis, a highly active tyrosine hydroxylase was created with increased titers for L-DOPA (2.8-fold) and dopamine (7.4-fold). This innovative research fully recovered the 7step pathway from L-tyrosine to (S)-reticuline [50]. The isomerization of neopinone to codeinone in opium poppy was formerly assumed spontaneous. However, it was found recently that this critical step in morphine biosynthesis is catalyzed by neopinone isomerase (NISO) [33]. Together with another recent discovery of thebaine synthase [51], NISO considerably increased codeine synthesis in yeast on account of neopine.

One comprehensive study showed that it is possible to biomanufacture thebaine and hydrocodone in yeast starting from sugar. As a result of this manipulation in opioid biosynthesis, yeast strains expressed 21 (thebaine) and 23 (hydrocodone) enzymes from plants, mammals, bacteria, and yeast itself. This synthetic biology approach emphasizes the potential of yeast as a production chassis for BIAs. However, rigorous improvements are still required to reach economically feasible levels of production [52].

Another study demonstrates that $E$. coli may also serve as a platform for opiates synthesis. Thebaine production based on 4 engineered strains and starting from glycerol achieved yields of $2.1 \mathrm{mg} / \mathrm{L}$, which is a 300-fold increase from other yeast systems [53].

Although the cultivation of opium poppy is still the only source of morphinans, the utilization of genetically modified microbes as cell factories represents an increasingly valuable strategy in the biomanufacturing of $P$. somniferum alkaloids. All the studies above are viewed as proof-of-principle, and yet many efforts are needed to accelerate the development of heterologous systems that can produce high-value BIAs at a commercial scale. Thus, biotechnological production may help to circumvent any uncertainties in the opiates supply due to seasonal, environmental or political factors and avoid any illicit use of this clinically important class of plant-derived narcotic analgesics.

\section{Monoterpenoid indole alkaloids}

The MIAs represent a class of plant secondary metabolites with more than 2000 compounds with pharmacological activity [54]. The alkaloids with antineoplastic properties from this large class of compounds, vinblastine and vincristine, are found in trace amounts in the leaves of C. roseus (Madagascar periwinkle, family Apocynaceae).

These valuable alkaloids are formed through condensation from 2 precursors: catharanthine and vindoline. The MIA biosynthesis is quite complex because it includes 31 enzymatic steps from geranyl pyrophosphate (GPP) [9]. Furthermore, the MIA metabolism is localized in different plant tissues (phloem-associated parenchyma, epidermis, mesophyll, laticifer) and subcellular organelles (i. e., plastids, nucleus, ER, and vacuoles) [54-56]. The production of the MIAs in yeast consists of 3 parts: the early stage (from the plastid methylerythritol 4-phosphate (MEP) pathway to the central metabolite strictosidine), the central stage (from strictosidine to tabersonine or catharanthine), and the final stage (the conversion of tabersonine to vindoline) [57].

It has been comprehensively shown that strictosidine can be synthesized de novo in an S. cerevisiae from 14 known MIA pathway genes. Seven gene additions and 3 gene deletions boost the MIA secondary metabolism [40]. This yeast system accumulated strictosidine at levels of $\approx 0.5 \mathrm{mg} / \mathrm{L}$. Despite the low titers of strictosidine in this yeast strain, the reconstruction of the early stage from MIA metabolism is a critical first step toward the overall heterologous production of vinblastine and vincristine. Furthermore, this heterologous system can be used to examine the differenzial intracellular compartmentalization of MIA biosynthetic enzymes and its impact on production levels. For example, strictosidine synthase is located in the vacuole, and geraniol synthase is expressed in the chloroplast of plant cells. Therefore, the truncated versions of both genes without a localization signal sequence were used to circumvent potential bottlenecks regarding intracellular membrane transport.

After completing the first stage of the MIA biosynthesis, several bridging enzymes, which form the middle part of the MIA multistep biosynthesis, have been identified. Six genes were described and functionally characterized in yeast, resulting in the conversion of 19E-geissoschizine to O-acetylstemmadenine [58]. Both missing steps to tabersonine were elucidated independently by 2 research groups $[59,60]$.

The identification of tabersonine 3-oxygenase (T3O) and tabersonine 3-reductase (T3R) completes the molecular and biochemical characterization of the only remaining unknown reactions in the tabersonine-to-vindoline pathway (i. e., in the terminal MIA pathway stage). T3O and T3R were expressed in yeast together with 5 formerly identified genes from C. roseus to yield $1.1 \mathrm{mg} / \mathrm{L}$ of vindoline after feeding with tabersonine [61].

The identification of these missing components secured the framework for the future reconstruction of the whole MIA path- 
way. Hopefully, a fully de novo pathway to vinblastine in a prototype will be available soon in microbial systems, followed by a further improvement of end-product titers [57].

\section{Cannabinoids}

Cannabinoids have emerged as an attractive target for microbial biosynthesis due to their growing pharmaceutical significance. The entire biosynthesis of the major cannabinoids was realized heterologously for the first time in S. cerevisiae from the simple sugar galactose [62]. This reconstitution utilized the yeast hexanoyl-CoA biosynthetic machinery, to which was introduced a series of $C$. sativa genes, encoding a tetraketide synthase, an olivetolic acid cyclase, and an acyl-activating enzyme to produce olivetolic acid (OA). The crucial step in the reconstruction was the formation of the intermediate from the central hub in the cannabinoid biosynthesis: cannabigerolic acid (CBGA). CBGA is synthesized through the coupling of OA and the mevalonate acid (MVA) pathway intermediate GPP. Additionally, a GPP-overexpressing strain and a mutant version of the endogenous farnesyl pyrophosphate synthase ERG20 were constructed to produce GPP.

However, the patented enzyme from $C$. sativa (CsPT1), responsible for this step, failed to show any activity. Therefore, other genes with a similar function from other organisms were screened. Among those potential candidates was also a soluble prenyltransferase NphB from Streptomyces sp. strain CL190, previously used to replace the native CBGA synthase from $C$. sativa [63]. The transcriptome mining ended up with a gene candidate whose truncated version yielded $1.4 \mathrm{mg} / \mathrm{L} \mathrm{CBGA}$ from galactose. The Cannabis synthases, responsible for the terminal steps from CBGA to tetrahydrocannabinolic acid (THCA) and cannabidiolic acid (CBDA), were expressed with a vacuolar localization tag to enable accumulation levels of $2.3 \mathrm{mg} / \mathrm{L}$ THCA and $4.2 \mu \mathrm{g} / \mathrm{L} \mathrm{CBDA}$.

Despite the low cannabinoid levels in $S$. cerevisiae, this work represents a starting point for further optimization studies leading to commercial production of THCA and CBDA, which can be converted easily into tetrahydrocannabinol and cannabidiol after heat exposure. Additionally, the same research group members explored the opportunity to produce unnatural cannabinoids with modified side groups via the established cannabinoid pathway.

The glycosylation of cannabinoids represents another promising opportunity for the biosynthesis of unnatural cannabinoids with improved water solubility, bioavailability, and site-specific drug targeting. For instance, it was shown for the first time that the UDP-glycosyltransferases from Stevia rebaudiana and Oryza sativa were able to produce cannabinoid mono-, di-, tri-, and tetraglycosides in vitro [64].

\section{Ginsenosides}

Ginsenosides are glycosylated triterpenes isolated from the Panax species that exert various beneficial biological effects. However, it takes about 6 years for the roots to reach a harvesting stage and produce the commercial ginseng material. Therefore, microbial systems producing ginsenosides may become an interesting manufacturing alternative to the wild ginseng roots and plant cell cultures.

Ginsenosides are divided into 2 groups of natural compounds: dammarane (tetracyclic)-type and oleanane (pentacyclic)-type.
Dammarane-type ginsenosides are the major constituents that are obtained from 2 aglycones: protopanaxadiol (Rb1, Rb2, Rc, $\mathrm{Rd}, \mathrm{Rh} 2$, and $\mathrm{Rg} 3$ ) and protopanaxatriol (Re, Rf, and Rg1) [65].

The highest reported ginsenoside aglycone titer in a heterologous system was obtained recently in yeast for protopanaxadiol: $529.0 \mathrm{mg} / \mathrm{L}$ of PPD in shake flasks and $11.02 \mathrm{~g} / \mathrm{L}$ in $10 \mathrm{~L}$ fed-batch fermentation. This remarkable yield was achieved by overexpression of the MVA genes and optimization of the activities of cytochrome P450 enzymes in yeast. Moreover, the C3-OH glycosylation efficiency was improved to produce ginsenoside Rh2 by increasing the copy number of UDP-glycosyltransferase (UGT) $\mathrm{Pg} 45$, engineering its promoter, in vivo-directed evolution and searching for more active UGTs from other plant species. Following this optimization strategy, the yeast cell factory reached an outstanding Rh2 level of $179.3 \mathrm{mg} / \mathrm{L}$ in shake flasks and $2.25 \mathrm{~g} / \mathrm{L}$ in $10 \mathrm{~L}$ fed-batch fermentation. This is the highest yield of ginsenoside Rh2 in engineered microbes as well as a glycosylated natural product. However, it is necessary to conduct additional pilot plant tests in larger fermenters to validate the commercial feasibility of this approach [66]. Furthermore, similar production levels still need to be achieved for the other ginsenoside types.

\section{Paclitaxel}

The diterpenoid paclitaxel (Taxol), an efficient therapeutic agent for treating several types of cancer, was isolated initially from the bark of Pacific yew (T. brevifolia) more than 5 decades ago. However, the accumulation levels of paclitaxel in yew plants are very low: about $0.01 \%$ of the dry weight of bark [67]. As a result, T. brevifolia has become a plant species in a near-threatened state due to its overharvesting [17]. Industrial production using total chemical synthesis is also hampered because of its complexity. Therefore, different strategies are employed to produce this valuable compound, such as plant cells cultivation, semi-synthesis, or metabolic engineering of microbial cells [68].

The manufacturing of paclitaxel on an industrial scale is directed toward the semi-synthesis from 2 precursors, baccatin III and 10-deacetylbaccatin III, obtained from renewable sources like the needles of the Himalayan yew or Taxus plant cell cultures [69]. Taxus cell culture can also produce paclitaxel entirely, following methyl jasmonate elicitation, to reach accumulation levels of $110 \mathrm{mg} / \mathrm{L}[70]$.

Most steps from paclitaxel biosynthesis are known, and the corresponding enzymes and encoding genes have already been characterized in different heterologous systems. However, the metabolic pathway of paclitaxel is rather complicated; therefore, its alternative recombinant production remains still in its infancy [71]. There is a partial success only in the initial part of the paclitaxel biosynthesis to taxadiene. The highest taxadiene titer reported so far is about $1 \mathrm{~g} / \mathrm{L}$ in fed-batch bioreactor fermentation with $E$. coli after engineering the native upstream MEP-pathway (forming isopentenyl pyrophosphate) and the heterologous downstream pathway (forming terpenoid). However, when taxadiene- $5 \alpha$-hydroxylase $(\mathrm{T} 5 \alpha \mathrm{H})$, responsible for the oxidation of taxadiene to taxadien- $5 \alpha$-ol, was introduced in the next step, the titers reduced significantly to $50 \mathrm{mg} / \mathrm{L}$ of taxadiene- $5 \alpha$-ol [72].

Therefore, the research efforts in recent years are focused on resolving the $\mathrm{T} 5 \alpha \mathrm{H}$ bottleneck. Different approaches were applied 
to overcome this obstacle (i. e., optimization of $\mathrm{T} 5 \alpha \mathrm{H}$ expression, improvement of the interaction with cytochrome $\mathrm{P} 450$ reductase, intracellular compartmentalization, the use of riboregulated switchable feedback promoters, etc.). The latest progress in transcriptomic data mining and the expected assembly of a high-resolution genome of Taxus species soon may also contribute to overcoming the $\mathrm{T} 5 \alpha \mathrm{H}$ bottleneck and reconstituting the entire paclitaxel biosynthesis [73].

\section{Heterologous Expression of Therapeutic Proteins in Plants}

Plants have been used traditionally either as a commercial source of valuable end-up natural products or as a genetic pool for elucidation of secondary metabolic steps with a subsequent heterologous expression in microbial systems. The advancements in DNA recombinant technology in the past 3 decades also allowed biomanufacturing of therapeutic proteins in plants. Thus, plants became a beneficial production platform for antibodies, vaccines, human blood products, and growth regulators. As a result, a new applied field emerged named "plant molecular farming". Some authors prefer using the term "plant molecular pharming" (PMP) or even "biopharming" as the majority of these recombinant proteins are plant-derived pharmaceutical proteins or biopharmaceuticals $[22,74,75]$.

The most frequently utilized platforms for protein production nowadays are Chinese hamster ovary cells (CHO) and E. coli, followed by S. cerevisiae and murine myeloma cells [76]. However, plant-based systems have several major advantages over the traditional prokaryotic and eukaryotic protein production systems concerning manufacturing rapidity, cost, and safety. Prokaryote cells are generally used for the recombinant expression of small proteins $(<30 \mathrm{kDa})$; the fully formed large proteins are easier produced in eukaryote systems such as plants [77]. Noneukaryotic cells display difficulties in producing the correct folding of human proteins, and insoluble protein formation can be observed when the target protein is overexpressed. Plants can correctly fold and assemble full-size immunoglobulins and even secretory antibodies [78].

The posttranslational modifications (PTMs), such as the formation of covalent bonds, disulphide bridges, glycosylation, etc., are essential for protein functionality. Plants can introduce such PTMs that may affect several therapeutic proteins like serum half-life, immunogenicity, effector function, and solubility [79]. The glycosylation capability of plants is an advantage compared to prokaryotic expression systems. The glycosylation capacity might be limited, even in insect and yeast cells [80]. However, the recombinant proteins expressed in plants lack the human type of glycosylation with terminal sialic acid residues and display a typical $\beta 1,2$ xylose and $\alpha 1,3$ fucose pattern of glycosylation, which may provoke an immune response when administered intravenously [81]. The CRISPR/Cas9 system has been recently applied to introduce mutations into 2 copies of $N$. benthamiana XyIT [82]. Transcription activator-like effector nucleases (TALENs) have also been used to knockout XylT and FucT genes in an attempt to reduce such an undesired immunogenic response [83]. The development of modern genome editing tools may lead to the introduction of whole glycosylation pathways to produce therapeutic proteins in plants with defined human $\mathrm{N}$ - and $\mathrm{O}$-glycan patterns [84]. The production of therapeutic proteins in plants also reduces the risk of potential contamination with animal pathogens (prions, viruses, and mycoplasmas).

The cost of PMP-products is only $0.1 \%$ of mammalian cells and $2-10 \%$ of microbial systems [21]. The following plant systems for expression of foreign proteins are exploited: transgenic plants with nuclear/chloroplast transformed genomes, cell suspension cultures, and transient expression. The recombinant proteins can be targeted to various subcellular organelles or compartments such as ER, apoplast, cytosol, and chloroplasts to find the most appropriate cellular surroundings for their accumulation [85].

In summary, plant-based platforms are a favorable in-between production system that can produce larger therapeutic proteins (compared to microbial systems). They are easily scalable and cost-effective, with a lower risk of pathogens (compared to mammalian systems) and toxic contaminants [76]. Plant expression systems are unlikely to replace the golden standards in the industry for protein manufacturing, such as $E$. coli and $\mathrm{CHO}$ cells, because plants cannot yet compete with the yields of these well-established industrial systems. Other concerns are also the potential risk of environmental containment, the presence of nonhuman glycosylation, and the lack of regulatory approval. Therefore, PMP technologies for both upstream production and downstream processing have to be developed further to comply with the pharma industry's Good Manufacturing Practice (GMP) requirements. To achieve this goal, the diverse production systems and techniques used in PMP need to be consolidated to establish standardized procedures [86].

\section{Examples from the PMP Showcase}

Human growth hormone was the first-plant-derived recombinant therapeutic protein, expressed in sunflower and tobacco cells [87]. The first report about the efficient production and assembly of functional antibodies in transgenic plants occurred 3 years later. A functional murine full-size IgG1 antibody reached $1.3 \%$ of total leaf protein. The specific binding of the antigen recognized by these antibodies was similar to the antibodies derived by hybridoma technology [88]. Since then, many pharmaceutical proteins have been expressed and characterized successfully in plants.

The first breakthrough product in the PMP field is the experimental drug called ZMapp, which showed immunological activity during the 2014 Ebola outbreak in West Africa. The plant production technology for therapeutic proteins attracted attention when 5 from 7 health aid workers survived this epidemic after receiving ZMapp [89]. ZMapp is an optimized combination from 2 previous antibody cocktails, ZMAb (consisting of murine monoclonal antibodies (mAbs) m1H3, m2G4, and m4G7) and MB-003 (consisting of human or human-mouse chimeric mAbs c13C6, h13F6, and c6D8). To extend the antibody half-life in humans and to facilitate clinical acceptance, the ZMAb components were first chimerized and then produced in $N$. benthamiana together with MB-003 candidates to select the final therapeutic combination. The end-cocktail represented a triple combination of anti- 
bodies (c13C6, c2G4, and c4G7), which was manufactured using the large-scale, GMP-compatible rapid antibody manufacturing platform and magnICON vectors [90-92]. ZMapp demonstrated $100 \%$ rescue of rhesus macaques when treatment is initiated up to 5 days post-challenge, These results secured future development of this cocktail against the Ebola virus for clinical use [93].

Anti-Ebola virus therapy was additionally optimized to the chimeric MIL77E mAb combination of only 2 antibodies, based on c13C6 and c2G4 mAbs from ZMapp, containing a few amino acids changes [94]. This cocktail conferred $100 \%$ protection in nonhuman primates infected with the Ebola virus and was produced in $\mathrm{CHO}$ cells. Although the MIL77E mAb combination is designed for future manufacturing in mammalian cells, the ZMapp story has contributed to the growing popularity and commercialization of PMP.

The transient expression system in $N$. benthamiana, based on viral vectors and the agroinfiltration technique with Agrobacterium tumefaciens, is currently the most preferred platform for producing recombinant proteins in plants. The key advantage of this recombinant DNA technology is the high levels of protein expression in plants, achieved within a short duration of time. - Table 3 summarizes selected PMP examples in different therapeutic areas, following transient expression in $N$. benthamiana plants.

The transient plant expression system can be employed for the rapid production of recombinant proteins at high yields to meet the sudden demand for the production of emergency vaccines during viral outbreaks [95]. Therefore, $N$. benthamiana can also become a promising host for vaccine manufacturing to fight the COVID-19 pandemic [96]. For instance, 2 companies with extensive PMP expertise registered clinical trials for COVID-19 vaccines presently. The clinical studies of Kentucky BioProcessing (ClinicalTrials.gov identifier: NCT04473690) and Medicago (ClinicalTrials.gov Identifier: NCT04636697) have estimated enrollment of 180 and 30,918 participants, respectively. The outcomes of these clinical trials may presumably determine whether other PMP players will also join the combat against this global pandemic.

\section{Commercialization Examples}

Different aspects (i. e., the levels of the biologically active natural product in the native producer, the daily intake dose by the patient, the economic feasibility of the manufacturing process, etc.) have been taken into consideration when the acceptable yield for the heterologous production of a certain low molecular compound is determined. In general, titers over $1 \mathrm{~g} / \mathrm{L}$ are considered outstanding for any heterologous system, producing small molecules [38].

The assessment of yield optimization in a given heterologous production platform must be considered on a case-by-case basis for each natural compound of interest. For example, the reported hydrocodone titers in yeast are $<1 \mu \mathrm{g} / \mathrm{L}$, while a single dose of hydrocodone, as used in Vicodin $(5 \mathrm{mg})$, would require thousands of liters of fermentation broth. Furthermore, the conversion rate of thebaine to morphine is $1.5 \%$. Therefore, the overall yield improvement of morphine production using such a yeast strain should be of a factor of $\approx 7 \times 10^{6}$ [52].
One landmark success in metabolic engineering is the complete biosynthesis of artemisinic acid in $\mathrm{S}$. cerevisiae, yielding impressive fermentation titers of $25 \mathrm{~g} / \mathrm{L}$. Next, a semisynthetic approach was developed to convert artemisinic acid to artemisinin using a chemical source of singlet oxygen instead of specialized photochemical equipment. Based on yeast strain engineering, fermentation and artemisinin synthetic chemistry, this combined production technology paved the way for an industrial application of this valuable antimalarial drug and its independent supply from a botanical source [97]. As a result, the Sanofi company opened a manufacturing site in Italy for artemisinin production, which secured approximately one-third of the global annual demand in 2014 with its 55-60 tons [2].

The only PMP-product that has entered the market is ELELYSO (taliglucerase alfa) from Protalix BioTherapeutics (Israel). In 2012, the US Food and Drug Administration approved this plant-derived enzyme for replacement therapy of adult patients with Gaucher disease, a rare genetic disorder in which the patients fail to produce the enzyme glucocerebrosidase [98]. ELELYSO is produced in genetically engineered carrot cells and naturally contains terminal mannose residues on its complex glycans. Therefore, the plant-produced glucocerebrosidase does not need exposure of mannose residues in vitro as required for the market competitor Cerezyme produced in CHO cells [99]. The long-term safety and efficacy of taliglucerase alfa was proved by 6 clinical studies in adults and children with Gaucher disease [100].

\section{Conclusion and Future Prospects}

This review aims to show the growing potential of medicinal plants beyond their traditional application as a source of pharmaceutically important natural products. This new potential is also related to recombinant DNA technology. However, the past 30 years of application of DNA recombinant technology in plants have shown that the road to commercially viable titers is neither straightforward nor secure and that significant improvement is necessary before success is realized.

On the other hand, the progress made indicates that metabolic engineering and synthetic biology greatly impact the biomanufacturing of high-value products from plants [38]. The heterologous expression in host organisms represents an increasingly valuable and feasible strategy for exploiting the wide chemical diversity in nature without endangering plant biodiversity.

The recent advancements in high-throughput sequencing, genome editing tools like zinc-finger nucleases, transcription activator-like effector nucleases (TALENs), and CRISPR/Cas9 system are very useful for manipulating secondary metabolism in plants [24]. These genome editing techniques may also enable precision engineering of the therapeutic proteins with bespoke glycan decoration and lead to increased accumulation levels of the target biopharmaceutical by knocking out the genes encoding plant proteases [101]. Cell-free synthesis systems can also be employed to manufacture various protein-based products or metabolites [102-105]. The product optimization based on a simultaneous global exploration of various factors may achieve more reproducible yields than assessing one factor at a time [106]. Such a systematic workflow may be used efficiently to improve both metab- 
- Table 3 Selected examples of recombinant proteins expressed transiently in N. benthamiana.

\begin{tabular}{|c|c|c|c|}
\hline Therapeutic target & Recombinant protein & Expression level & Reference \\
\hline \multirow[t]{3}{*}{ Cancer } & ML-II lectin & $60 \mathrm{mg} / \mathrm{kg} \mathrm{FW}$ & [123] \\
\hline & Rituximab & $385 \mathrm{mg} / \mathrm{kg} \mathrm{FW}$ & [124] \\
\hline & BR55-2 & $30 \mathrm{mg} / \mathrm{kg} \mathrm{FW}$ & [125] \\
\hline Chikungunya virus & CHKV mAb & $100 \mu \mathrm{g} / \mathrm{g} F W$ & [126] \\
\hline \multirow[t]{2}{*}{ Cholera } & Cholera toxin B subunit & $3.1 \mathrm{~g} / \mathrm{kg} \mathrm{FW}$ & [127] \\
\hline & Cholera toxin B subunit & $0.5-1.5 \mathrm{~g} / \mathrm{kg} \mathrm{FW}$ & [128] \\
\hline \multirow[t]{3}{*}{ Dengue virus } & E60 & $120 \mu \mathrm{g} / \mathrm{g} \mathrm{FW}$ & [129] \\
\hline & cEDIII & $5.2 \mathrm{mg} / \mathrm{g} \mathrm{FW}$ & [130] \\
\hline & cEDIII-Co1 & $4.8 \mathrm{mg} / \mathrm{g} \mathrm{FW}$ & [130] \\
\hline Ebola virus & $6 \mathrm{D} 8$ & $1.21 \mathrm{mg} / \mathrm{g} \mathrm{FW}$ & [131] \\
\hline Erythropoetin & rhEPO & $85 \mathrm{mg} / \mathrm{kg} \mathrm{FW}$ & [132] \\
\hline \multirow[t]{3}{*}{ Fabry disease } & $\alpha-G A L$ & $71 \mathrm{nmol} / \mathrm{h} / \mu \mathrm{g}$ TP & [133] \\
\hline & $\alpha-N A G A L$ & $5 \mathrm{nmol} / \mathrm{h} / \mu \mathrm{g} \mathrm{TP}$ & [133] \\
\hline & $\alpha$-NAGALEL & $7 \mathrm{nmol} / \mathrm{h} / \mathrm{\mu g} \mathrm{TP}$ & [133] \\
\hline \multirow[t]{2}{*}{ Influenza } & Hemagglutinin VLPs & $50 \mathrm{mg} / \mathrm{kg} \mathrm{FW}$ & [134] \\
\hline & rHAO & $0.2 \mathrm{~g} / \mathrm{kg} \mathrm{FW}$ & [135] \\
\hline \multirow[t]{2}{*}{ Hepatitis B virus (HBV) } & HBV surface antigen & $295 \mu \mathrm{g} / \mathrm{g} \mathrm{FW}$ & [136] \\
\hline & HBV core antigen & $0.2-1 \mathrm{mg} / \mathrm{g} \mathrm{FW}$ & [137] \\
\hline Human epidermal growth factor & hEGF & $15.695 \mu \mathrm{g} / \mathrm{g} \mathrm{FW}$ & [138] \\
\hline \multirow[t]{4}{*}{ Human immunodeficiency virus } & HIV Env gp140 & $5-6 \mathrm{mg} / \mathrm{kg} \mathrm{FW}$ & [139] \\
\hline & VRC01 $_{\mathrm{Fab}}$-Avaren & $40 \mathrm{mg} / \mathrm{kg} \mathrm{FW}$ & {$[140]$} \\
\hline & CAP256-VRC26.08 & $489 \mathrm{mg} / \mathrm{kg} \mathrm{FW}$ & [141] \\
\hline & CAP256-VRC26.09 & $487 \mathrm{mg} / \mathrm{kg} \mathrm{FW}$ & [141] \\
\hline Herpes simplex virus & HSV8 & $1.42 \mathrm{mg} / \mathrm{g} \mathrm{FW}$ & [131] \\
\hline Malaria & $\mathrm{CCT}$ & $2 \mathrm{mg} / \mathrm{g} \mathrm{FW}$ & [142] \\
\hline Rabies & E559/62-71-3 mAbs & $490 \mathrm{mg} / \mathrm{kg} \mathrm{FW}$ & [143] \\
\hline \multirow[t]{5}{*}{ SARS-CoV-2 } & mAb B38 & $4 \mu \mathrm{g} / \mathrm{g} F W$ & [144] \\
\hline & $\mathrm{mAb} \mathrm{H} 4$ & $35 \mu \mathrm{g} / \mathrm{g} \mathrm{FW}$ & [144] \\
\hline & ACE2-FC & $100 \mu \mathrm{g} / \mathrm{g} \mathrm{FW}$ & [145] \\
\hline & ACE2-FC & $\approx 80 \mu \mathrm{g} / \mathrm{g} \mathrm{FW}$ & [146] \\
\hline & CR3022 mAb & $130 \mu \mathrm{g} / \mathrm{g} F W$ & [147] \\
\hline \multirow[t]{5}{*}{ West Nile virus } & pE16 & $0.74 \mathrm{mg} / \mathrm{g} \mathrm{FW}$ & {$[148]$} \\
\hline & pE16scFv-CH & $0.77 \mathrm{mg} / \mathrm{g} \mathrm{FW}$ & [148] \\
\hline & DIII & $73 \mu \mathrm{g} / \mathrm{g} \mathrm{FW}$ & [149] \\
\hline & $\mathrm{HBCAg-wDIII}$ & $1.2 \mathrm{mg} / \mathrm{g} \mathrm{FW}$ & [150] \\
\hline & $\mathrm{E} 16 \mathrm{mAb}$ & $339.9 \mu \mathrm{g} / \mathrm{g} \mathrm{FW}$ & [151] \\
\hline \multirow[t]{3}{*}{ Zika virus } & C2A10G6 & $1.47 \mathrm{mg} / \mathrm{g} \mathrm{FW}$ & [131] \\
\hline & IgG-ZE3 & $1.5 \mathrm{mg} / \mathrm{g} \mathrm{FW}$ & [152] \\
\hline & ZIKVE & $160 \mu \mathrm{g} / \mathrm{g} \mathrm{FW}$ & [153] \\
\hline
\end{tabular}


olite or protein product levels in any heterologous expression system $[107,108]$.

All these approaches may contribute to further optimization. We hope to see in the near future more industrial examples based on the recombinant DNA technology for manufacturing pharmaceutically valuable products with plant origin.

\section{Acknowledgements}

The review article is funded by the VIPplus Program of the German Federal Ministry of Education and Research (project No. 03VP06370).

\section{Conflict of Interest}

The authors declare that they have no conflict of interest.

\section{References}

[1] Gurib-Fakim A. Medicinal plants: traditions of yesterday and drugs of tomorrow. Mol Aspects Med 2006; 27: 1-93. doi:10.1016/j. mam.2005.07.008

[2] Kayser O. Ethnobotany and medicinal plant biotechnology: from tradition to modern aspects of drug development. Planta Med 2018; 84: 834-838. doi:10.1055/a-0631-3876

[3] Bandaranayake WM. Quality Control, Screening, Toxicity, and Regulation of herbal Drugs. In: Ahmad I, Aqil F, Owais M, eds. Modern Phytomedicine Turns Medicinal Plants into Drugs; 2006: 25-57. doi:10.1002/ 9783527609987.CH2

[4] Newman DJ, Cragg GM. Natural products as sources of new drugs over the nearly four decades from 01/1981 to 09/2019. J Nat Prod 2020; 83: 770-803. doi:10.1021/acs.jnatprod.9b01285

[5] Lautié E, Russo O, Ducrot P, Boutin JA. Unraveling plant natural chemical diversity for drug discovery purposes. Front Pharmacol 2020; 11: 397. doi:10.3389/fphar.2020.00397

[6] Janssen B, Schäfer B. Galantamine. ChemTexts 2017; 3: 1-21. doi:10.1007/s40828-017-0043-y

[7] Chu LL, Montecillo JA V, Bae H. Recent advances in the metabolic engineering of yeasts for ginsenoside biosynthesis. Front Bioeng Biotechnol 2020; 8: 139. doi:10.3389/fbioe.2020.00139

[8] Durazzo A, Lucarini M, Santini A. Nutraceuticals in human health. Foods 2020; 9: 370. doi:10.3390/foods9030370

[9] Ramzi AB, Baharum SN, Bunawan H, Scrutton NS. Streamlining natural products biomanufacturing with omics and machine learning driven microbial engineering. Front Bioeng Biotechnol 2020; 8: 608918. doi:10.3389/fbioe.2020.608918

[10] Nielsen J, Keasling JD. Engineering cellular metabolism. Cell 2016; 164: 1185-1197. doi:10.1016/j.cell.2016.02.004

[11] Dastmalchi M, Park MR, Morris JS, Facchini P. Family portraits: the enzymes behind benzylisoquinoline alkaloid diversity. Phytochem Rev 2018; 17: 249-277. doi:10.1007/s11101-017-9519-z

[12] Carvalho Â, Hansen EH, Kayser O, Carlsen S, Stehle F. Designing microorganisms for heterologous biosynthesis of cannabinoids. FEMS Yeast Res 2017; 17: fox037. doi:10.1093/femsyr/fox037

[13] Dziggel C, Schäfer H, Wink M. Tools of pathway reconstruction and production of economically relevant plant secondary metabolites in recombinant microorganisms. Biotechnol J 2017; 12: 1600145. doi:10.1002/biot.201600145

[14] Kim YJ, Lee OR, Oh JY, Jang MG, Yang DC. Functional analysis of 3-hydroxy-3-methylglutaryl coenzyme a reductase encoding genes in triterpene saponin-producing ginseng. Plant Physiol 2014; 165: 373-387. doi:10.1104/pp.113.222596
[15] Yang JL, Hu ZF, Zhang TT, Gu AD, Gong T, Zhu P. Progress on the studies of the key enzymes of ginsenoside biosynthesis. Molecules 2018; 23: 589. doi:10.3390/molecules23030589

[16] Pan Q, Mustafa NR, Tang K, Choic YH, Verpoorte R. Monoterpenoid indole alkaloids biosynthesis and its regulation in Catharanthus roseus: a literature review from genes to metabolites. Phytochem Rev 2016; 15: 221-250. doi:10.1007/s11101-015-9406-4

[17] Scossa F, Benina M, Alseekh S, Zhang Y, Fernie AR. The integration of metabolomics and next-generation sequencing data to elucidate the pathways of natural product metabolism in medicinal plants. Planta Med 2018; 84: 855-873. doi:10.1055/a-0630-1899

[18] Thamm AMK, Qu Y, De Luca V. Discovery and metabolic engineering of iridoid/secoiridoid and monoterpenoid indole alkaloid biosynthesis. Phytochem Rev 2016; 15: 339-361. doi:10.1007/s11101-016-9468-y

[19] Ionkova I. Anticancer lignans - from discovery to biotechnology. Mini-Reviews Med Chem 2011; 11: 843-856. doi:10.2174/ 138955711796575425

[20] Shanmugaraj B, I. Bulaon C], Phoolcharoen W. Plant molecular farming: A viable platform for recombinant biopharmaceutical production. Plants 2020; 9: 842. doi:10.3390/plants9070842

[21] Yao ], Weng Y, Dickey A, Wang KY. Plants as factories for human pharmaceuticals: Applications and challenges. Int J Mol Sci 2015; 16: 2854928565. doi:10.3390/ijms161226122

[22] Kermode AR, Jiang L. Molecular Pharming. Hoboken, NJ, USA: John Wiley \& Sons, Inc.; 2018. doi:10.1002/9781118801512

[23] Samanani N, Liscombe DK, Facchini P]. Molecular cloning and characterization of norcoclaurine synthase, an enzyme catalyzing the first committed step in benzylisoquinoline alkaloid biosynthesis. Plant J 2004; 40: 302-313. doi:10.1111/j.1365-313X.2004.02210.x

[24] Rai A, Saito K, Yamazaki M. Integrated omics analysis of specialized metabolism in medicinal plants. Plant J 2017; 90: 764-787. doi:10.1111/ tpj. 13485

[25] Bergelson J, Roux F. Towards identifying genes underlying ecologically relevant traits in Arabidopsis thaliana. Nat Rev Genet 2010; 11: 867879. doi:10.1038/nrg2896

[26] Miura K, Ashikari M, Matsuoka M. The role of QTLs in the breeding of high-yielding rice. Trends Plant Sci 2011; 16: 319-326. doi:10.1016/j. tplants.2011.02.009

[27] Huang X, Wei X, Sang T, Zhao Q, Feng Q, Zhao Y, Li C, Zhu C, Lu T, Zhang Z, Li M, Fan D, Guo Y, Wang A, Wang L, Deng L, Li W, Lu Y, Weng Q, Liu K, Huang T, Zhou T, Jing Y, Li W, Lin Z, Buckler ES, Qian Q, Zhang QF, Li J, Han B. Genome-wide association studies of 14 agronomic traits in rice landraces. Nat Genet 2010; 42: 961-967. doi:10.1038/ng.695

[28] Matsuba Y, Nguyen TT, Wiegert K, Falara V, Gonzales-Vigil E, Leong B, Schäfer P, Kudrna D, Wing RA, Bolger AM, Usadel B, Tissier A, Fernie AR, Barry CS, Pichersky E. Evolution of a complex locus for terpene biosynthesis in solanum. Plant Cell 2013; 25: 2022-2036. doi:10.1105/ tpc. 113.111013

[29] Kellner F, Kim J, Clavijo B], Hamilton JP, Childs KL, Vaillancourt B, Cepela J, Habermann M, Steuernagel B, Clissold L, McLay K, Buell CR, O'Connor SE. Genome-guided investigation of plant natural product biosynthesis. Plant J 2015; 82: 680-692. doi:10.1111/tpj.12827

[30] Rai A, Kamochi H, Suzuki H, Nakamura M, Takahashi H, Hatada T, Saito $\mathrm{K}$, Yamazaki M. De novo transcriptome assembly and characterization of nine tissues of Lonicera japonica to identify potential candidate genes involved in chlorogenic acid, luteolosides, and secoiridoid biosynthesis pathways. J Nat Med 2017; 71: 1-15. doi:10.1007/s11418-016-1041-x

[31] Winzer T, Gazda V, He Z, Kaminski F, Kern M, Larson TR, Li Y, Meade F, Teodor R, Vaistij FE, Walker C, Bowser TA, Graham IA. A Papaver somniferum 10-gene cluster for synthesis of the anticancer alkaloid noscapine. Science 2012; 336: 1704-1708. doi:10.1126/science.1220757

[32] Miettinen K, Dong L, Navrot N, Schneider T, Burlat V, Pollier J, Woittiez L, van der Krol S, Lugan R, Ilc T, Verpoorte R, Oksman-Caldentey KM, Mar- 
tinoia E, Bouwmeester H, Goossens A, Memelink J, Werck-Reichhart D. The seco-iridoid pathway from Catharanthus roseus. Nat Commun 2014; 5: 3606. doi:10.1038/ncomms4606

[33] Dastmalchi M, Chen X, Hagel JM, Chang L, Chen R, Ramasamy S, Yeaman $S$, Facchini PJ. Neopinone isomerase is involved in codeine and morphine biosynthesis in opium poppy. Nat Chem Biol 2019; 15: 384-390. doi:10.1038/s41589-019-0247-0

[34] Quanbeck SM, Brachova L, Campbell AA, Guan X, Perera A, He K, Rhee SY, Bais P, Dickerson JA, Dixon P, Wohlgemuth G, Fiehn O, Barkan L, Lange I, Lange BM, Lee I, Cortes D, Salazar C, Shuman J, Shulaev V, Huhman DV, Sumner LW, Roth MR, Welti R, Ilarslan H, Wurtele ES, Nikolau BJ. Metabolomics as a hypothesis-generating functional genomics tool for the annotation of Arabidopsis thaliana genes of "unknown function”. Front Plant Sci 2012 3: 15. doi:10.3389/fpls.2012.00015

[35] García-Granados R, Lerma-Escalera JA, Morones-Ramírez JR. Metabolic engineering and synthetic biology: synergies, future, and challenges. Front Bioeng Biotechnol 2019; 7: 36. doi:10.3389/fbioe.2019.00036

[36] Keasling JD. Synthetic biology and the development of tools for metabolic engineering. Metab Eng 2012; 14: 189-195. doi:10.1016/j.ymben. 2012.01.004

[37] Cravens A, Payne J, Smolke CD. Synthetic biology strategies for microbial biosynthesis of plant natural products. Nat Commun 2019; 10: 1-12. doi:10.1038/s41467-019-09848-w

[38] O'Connor SE. Engineering of secondary metabolism. Annu Rev Genet 2015; 49: 71-94. doi:10.1146/annurev-genet-120213-092053

[39] Trenchard I], Siddiqui MS, Thodey K, Smolke CD. De novo production of the key branch point benzylisoquinoline alkaloid reticuline in yeast. Metab Eng 2015; 31: 74-83. doi:10.1016/j.ymben.2015.06.010

[40] Brown S, Clastre M, Courdavault V, O’Connor SE. De novo production of the plant-derived alkaloid strictosidine in yeast. Proc Natl Acad Sci U S A 2015; 112: 3205-3210. doi:10.1073/pnas.1423555112

[41] Butelli E, Titta L, Giorgio M, Mock HP, Matros A, Peterek S, Schijlen EG, Hall RD, Bovy AG, Luo J, Martin C. Enrichment of tomato fruit with health-promoting anthocyanins by expression of select transcription factors. Nat Biotechnol 2008; 26: 1301-1308. doi:10.1038/nbt.1506

[42] Minami H, Kim JS, Ikezawa N, Takemura T, Katayama T, Kumagai H, Sato F. Microbial production of plant benzylisoquinoline alkaloids. Proc Natl Acad Sci U S A 2008; 105: 7393-7398. doi:10.1073/pnas.0802981105.

[43] Thodey K, Galanie S, Smolke CD. A microbial biomanufacturing platform for natural and semisynthetic opioids. Nat Chem Biol 2014; 10: 837844. doi:10.1038/nchembio. 1613

[44] Li Y, Smolke CD. Engineering biosynthesis of the anticancer alkaloid noscapine in yeast. Nat Commun 2016; 7: 1-14. doi:10.1038/ ncomms12137

[45] Runguphan W, Qu X, O'Connor SE. Integrating carbon-halogen bond formation into medicinal plant metabolism. Nature 2010; 468: 461464. doi:10.1038/nature09524

[46] Hawkins KM, Smolke CD. Production of benzylisoquinoline alkaloids in Saccharomyces cerevisiae. Nat Chem Biol 2008; 4: 564-573. doi:10.1038/nchembio.105.

[47] Nakagawa A, Minami H, Kim JS, Koyanagi T, Katayama T, Sato F, Kumagai $\mathrm{H}$. A bacterial platform for fermentative production of plant alkaloids. Nat Commun 2011; 2: 326. doi:10.1038/ncomms1327

[48] Nakagawa A, Minami H, Kim JS, Koyanagi T, Katayama T, Sato F, Kumagai $\mathrm{H}$. Bench-top fermentative production of plant benzylisoquinoline alkaloids using a bacterial platform. Bioeng Bugs 2012; 3: 49-53. doi:10.4161/bbug.3.1.18446

[49] Fossati E, Ekins A, Narcross L, Zhu Y, Falgueyret JP, Beaudoin GA, Facchini PJ, Martin VJ. Reconstitution of a 10-gene pathway for synthesis of the plant alkaloid dihydrosanguinarine in Saccharomyces cerevisiae. Nat Commun 2014; 5: 3283. doi:10.1038/ncomms4283

[50] DeLoache WC, Russ ZN, Narcross L, Gonzales AM, Martin V], Dueber JE. An enzyme-coupled biosensor enables $(S)$-reticuline production in yeast from glucose. Nat Chem Biol 2015; 11: 465-471. doi:10.1038/ nchembio. 1816

[51] Chen X, Hagel JM, Chang L, Tucker JE, Shiigi SA, Yelpaala Y, Chen HY, Estrada R, Colbeck J, Enquist-Newman M, Ibáñez AB, Cottarel G, Vidanes GM, Facchini PJ. A pathogenesis-related 10 protein catalyzes the final step in thebaine biosynthesis article. Nat Chem Biol 2018; 14: 738-743. doi:10.1038/s41589-018-0059-7

[52] Galanie S, Thodey K, Trenchard IJ, Filsinger Interrante M, Smolke CD. Complete biosynthesis of opioids in yeast. Science 2015; 349: 10951100. doi:10.1126/science.aac9373

[53] Nakagawa A, Matsumura E, Koyanagi T, Katayama T, Kawano N, Yoshimatsu K, Yamamoto K, Kumagai H, Sato F, Minami H. Total biosynthesis of opiates by stepwise fermentation using engineered Escherichia coli. Nat Commun 2016; 7: 1-8. doi:10.1038/ncomms10390

[54] Guirimand G, Guihur A, Ginis O, Poutrain P, Héricourt F, Oudin A, Lanoue A, St-Pierre B, Burlat V, Courdavault V. The subcellular organization of strictosidine biosynthesis in Catharanthus roseus epidermis highlights several trans-tonoplast translocations of intermediate metabolites. FEBS | 2011; 278: 749-763. doi:10.1111/j.1742-4658.2010.07994.x

[55] Guirimand G, Guihur A, Poutrain P, Héricourt F, Mahroug S, St-Pierre B, Burlat V, Courdavault V. Spatial organization of the vindoline biosynthetic pathway in Catharanthus roseus. J Plant Physiol 2011; 168: 549557. doi:10.1016/j.jplph.2010.08.018

[56] St-Pierre B, Vazquez-Flota FA, De Luca V. Multicellular compartmentation of Catharanthus roseus alkaloid biosynthesis predicts intercellular translocation of a pathway intermediate. Plant Cell 1999; 11: 887-900. doi:10.1105/tpc.11.5.887

[57] Ozber N, Watkins JL, Facchini PJ. Back to the plant: overcoming roadblocks to the microbial production of pharmaceutically important plant natural products. I Ind Microbiol Biotechnol 2020; 47: 815-828. doi:10.1007/s10295-020-02300-9

[58] Qu Y, Easson MEAM, Simionescu R, Hajicek J, Thamm AMK, Salim V, De Luca $V$. Solution of the multistep pathway for assembly of corynanthean, strychnos, iboga, and aspidosperma monoterpenoid indole alkaloids from 19E-geissoschizine. Proc Natl Acad Sci U S A 2018; 115: 3180 3185. doi:10.1073/pnas.1719979115

[59] Caputi L, Franke ], Farrow SC, Chung K, Payne RME, Nguyen TD, Dang TT, Soares Teto Carqueijeiro I, Koudounas K, Dugé de Bernonville T, Ameyaw B, Jones DM, Vieira IJC, Courdavault V, O’Connor SE. Missing enzymes in the biosynthesis of the anticancer drug vinblastine in Madagascar periwinkle. Science 2018; 360: 1235-1239. doi:10.1126/science.aat4100

[60] Qu Y, Safonova O, De Luca V. Completion of the canonical pathway for assembly of anticancer drugs vincristine/vinblastine in Catharanthus roseus. Plant J 2019; 97: 257-266. doi:10.1111/tpj.14111

[61] Qu Y, Easson ML, Froese J, Simionescu R, Hudlicky T, De Luca V. Completion of the seven-step pathway from tabersonine to the anticancer drug precursor vindoline and its assembly in yeast. Proc Natl Acad Sci U S A 2015; 112: 6224-6229. doi:10.1073/pnas.1501821112

[62] Luo X, Reiter MA, d’Espaux L, Wong J, Denby CM, Lechner A, Zhang Y Grzybowski AT, Harth S, Lin W, Lee H, Yu C, Shin J, Deng K, Benites VT, Wang G, Baidoo EEK, Chen Y, Dev I, Petzold C], Keasling JD. Complete biosynthesis of cannabinoids and their unnatural analogues in yeast. Nature 2019; 567: 123-126. doi:10.1038/s41586-019-0978-9

[63] Zirpel B, Degenhardt F, Martin C, Kayser O, Stehle F. Engineering yeasts as platform organisms for cannabinoid biosynthesis. J Biotechnol 2017; 259: 204-212. doi:10.1016/j.jbiotec.2017.07.008

[64] Hardman JM, Brooke RT, Zipp BJ. Cannabinoid glycosides: in vitro production of a new class of cannabinoids with improved physicochemical properties. bioRxiv 2017: 104349. doi:10.1101/104349

[65] Dai Z, Wang B, Liu Y, Shi M, Wang D, Zhang X, Liu T, Huang L, Zhang X. Producing aglycons of ginsenosides in bakers' yeast. Sci Rep 2014; 4 : 3986. doi:10.1038/srep03698 
[66] Wang P, Wei W, Ye W, Li X, Zhao W, Yang C, Li C, Yan X, Zhou Z. Synthesizing ginsenoside Rh2 in Saccharomyces cerevisiae cell factory at high-efficiency. Cell Discov 2019; 5: 5. doi:10.1038/s41421-018-0075-5

[67] Witherup KM, Look SA, Stasko MW, Ghiorzi T], Muschik GM, Cragg GM. Taxus spp. needles contain amounts of Taxol comparable to the bark of Taxus brevifolia: analysis and isolation. J Nat Prod 1990; 53: 1249-1255. doi:10.1021/np50071a017

[68] Nazhand A, Durazzo A, Lucarini M, Mobilia MA, Omri B, Santini A. Rewiring cellular metabolism for heterologous biosynthesis of Taxol. Nat Prod Res 2020; 34: 110-121. doi:10.1080/14786419.2019.1630122

[69] Li ], Mutanda I, Wang K, Yang L, Wang J, Wang Y. Chloroplastic metabolic engineering coupled with isoprenoid pool enhancement for committed taxanes biosynthesis in Nicotiana benthamiana. Nat Commun 2019; 10 : 4850. doi:10.1038/s41467-019-12879-y

[70] Yukimune Y, Tabata H, Higashi Y, Hara Y. Methyl jasmonate-induced overproduction of paclitaxel and Baccatin III in Taxus cell suspension cultures. Nat Biotechnol 1996; 14: 1129-1132. doi:10.1038/nbt0996-1129

[71] Nowrouzi B, Li RA, Walls LE, d’Espaux L, Malcı K, Liang L, Jonguitud-Borrego N, Lerma-Escalera AI, Morones-Ramirez JR, Keasling JD, Rios-Solis L. Enhanced production of taxadiene in Saccharomyces cerevisiae. Microb Cell Fact 2020; 19: 200. doi:10.1186/s12934-020-01458-2

[72] Ajikumar PK, Xiao WH, Tyo KE, Wang Y, Simeon F, Leonard E, Mucha O, Phon TH, Pfeifer B, Stephanopoulos G. Isoprenoid pathway optimization for Taxol precursor overproduction in Escherichia coli. Science 2010; 330: 70-74. doi:10.1126/science.1191652

[73] Mutanda I, Li ], Xu F, Wang Y. Recent advances in metabolic engineering, protein engineering, and transcriptome-guided insights toward synthetic production of Taxol. Front Bioeng Biotechnol 2021; 9: 632269. doi:10.3389/fbioe.2021.632269

[74] Ibrahim A, Odon V, Kormelink R. Plant viruses in plant molecular pharming: Toward the use of enveloped viruses. Front Plant Sci 2019; 10: 803. doi:10.3389/FPLS.2019.00803

[75] Murphy DJ. Improving containment strategies in biopharming. Plant Biotechnol J 2007; 5: 555-569. doi:10.1111/j.1467-7652.2007.00278.x

[76] Burnett MJB, Burnett AC. Therapeutic recombinant protein production in plants: Challenges and opportunities. Plants, People, Planet 2020; 2: 121-132. doi:10.1002/ppp3.10073

[77] Demain AL, Vaishnav P. Production of recombinant proteins by microbes and higher organisms. Biotechnol Adv 2009; 27: 297-306. doi:10.1016/ j.biotechadv.2009.01.008

[78] Vasilev N, Smales CM, Schillberg S, Fischer R, Schiermeyer A. Developments in the production of mucosal antibodies in plants. Biotechnol Adv 2016; 34: 77-87. doi:10.1016/j.biotechadv.2015.11.002

[79] Lim Y, Wong NS, Lee YY, Ku SC, Wong DC, Yap MG. Engineering mammalian cells in bioprocessing-current achievements and future perspectives. Biotechnol Appl Biochem 2010; 55: 175-189. doi:10.1042/ BA20090363

[80] Marsian J, Lomonossoff GP. Molecular pharming-VLPs made in plants. Curr Opin Biotechnol 2016; 37: 201-206. doi:10.1016/j.copbio. 2015.12.007

[81] Gomord V, Fitchette AC, Menu-Bouaouiche L, Saint-Jore-Dupas C, Plasson C, Michaud D, Faye L. Plant-specific glycosylation patterns in the context of therapeutic protein production. Plant Biotechnol J 2010; 8: 564-587. doi:10.1111/j.1467-7652.2009.00497.x

[82] Vazquez-Vilar M, Bernabé-Orts JM, Fernandez-Del-Carmen A, Ziarsolo P, Blanca J, Granell A, Orzaez D. A modular toolbox for gRNA-Cas9 genome engineering in plants based on the GoldenBraid standard. Plant Methods 2016; 12: 10. doi:10.1186/s13007-016-0101-2

[83] Li], Stoddard T], Demorest ZL, Lavoie PO, Luo S, Clasen BM, Cedrone F, Ray EE, Coffman AP, Daulhac A, Yabandith A, Retterath AJ, Mathis L, Voytas DF, D'Aoust MA, Zhang F. Multiplexed, targeted gene editing in Nicotiana benthamiana for glyco-engineering and monoclonal antibody production. Plant Biotechnol ] 2016; 14: 533-542. doi:10.1111/pbi.12403
[84] Castilho A, Strasser R. Production of functionally active recombinant Proteins in Plants. In: Kermode AR, Jiang L, eds. Molecular Pharming. Hoboken, NJ, USA: John Wiley \& Sons, Inc.; 2018: 67-89. doi:10.1002/ 9781118801512.ch4

[85] Saberianfar R, Menassa R. Strategies to increase Expression and Accumulation of recombinant Proteins. In: Kermode AR, Jiang L, eds. Molecular Pharming. Hoboken, NJ, USA: John Wiley \& Sons, Inc.; 2018: 119-135. doi:10.1002/9781118801512.ch6

[86] Spiegel H, Stöger E, Twyman RM, Buyel JF. Current Status and Perspectives of the Molecular Farming Landscape. In: Kermode AR, Jiang L, eds. Molecular Pharming. Hoboken, NJ, USA: John Wiley \& Sons, Inc.; 2018. 1-23. doi:10.1002/9781118801512.ch1

[87] Barta A, Sommergruber K, Thompson D, Hartmuth K, Matzke MA Matzke AJ. The expression of a nopaline synthase-human growth hormone chimaeric gene in transformed tobacco and sunflower callus tissue. Plant Mol Biol 1986; 6: 347-357. doi:10.1007/BF00034942

[88] Hiatt A, Cafferkey R, Bowdish K. Production of antibodies in transgenic plants. Nature 1989; 342: 76-78. doi:10.1038/342076a0

[89] Park KY, Wi SJ. Potential of plants to produce recombinant protein products. J Plant Biol 2016; 59: 559-568. doi:10.1007/s12374-016-0482-9

[90] Olinger GG jr., Pettitt J, Kim D, Working C, Bohorov O, Bratcher B, Hiatt E, Hume SD, Johnson AK, Morton J, Pauly M, Whaley KJ, Lear CM, Biggins JE, Scully C, Hensley L, Zeitlin L. Delayed treatment of Ebola virus infection with plant-derived monoclonal antibodies provides protection in rhesus macaques. Proc Natl Acad Sci U S A 2012; 109: 18030-18035. doi:10.1073/pnas.1213709109

[91] Pettitt ], Zeitlin L, Kim DH, Working C, Johnson JC, Bohorov O, Bratcher B, Hiatt E, Hume SD, Johnson AK, Morton J, Pauly MH, Whaley KJ, Ingram MF, Zovanyi A, Heinrich M, Piper A, Zelko J, Olinger GG. Therapeutic intervention of Ebola virus infection in rhesus macaques with the MB-003 monoclonal antibody cocktail. Sci Transl Med 2013; 5: 199ra113. doi:10.1126/scitranslmed.3006608

[92] Zeitlin L, Pettitt ], Scully C, Bohorova N, Kim D, Pauly M, Hiatt A, Ngo L, Steinkellner $\mathrm{H}$, Whaley KJ, Olinger GG. Enhanced potency of a fucosefree monoclonal antibody being developed as an Ebola virus immunoprotectant. Proc Natl Acad Sci U S A 2011; 108: 20690-20694. doi:10.1073/pnas.1108360108

[93] Qiu X, Wong G, Audet J, Bello A, Fernando L, Alimonti JB, FaustherBovendo $\mathrm{H}$, Wei $\mathrm{H}$, Aviles J, Hiatt E, Johnson A, Morton J, Swope K, Bohorov O, Bohorova N, Goodman C, Kim D, Pauly MH, Velasco J, Pettitt J, Olinger GG, Whaley K, Xu B, Strong JE, Zeitlin L, Kobinger GP. Reversion of advanced Ebola virus disease in nonhuman primates with ZMapp. Nature 2014; 514: 47-53. doi:10.1038/nature13777

[94] Qiu X, Audet J, Lv M, He S, Wong G, Wei H, Luo L, Fernando L, Kroeker A, Fausther Bovendo H, Bello A, Li F, Ye P, Jacobs M, Ippolito G, Saphire EO, Bi S, Shen B, Gao GF, Zeitlin L, Feng J, Zhang B, Kobinger GP. Two-mAb cocktail protects macaques against the Makona variant of Ebola virus. Sci Transl Med 2016; 8: 329ra33. doi:10.1126/scitranslmed.aad9875

[95] LeBlanc Z, Waterhouse P, Bally J. Plant-based vaccines: The way ahead? Viruses 2020; 13: 5. doi:10.3390/v13010005

[96] Mahmood N, Nasir SB, Hefferon K. Plant-based drugs and vaccines for COVID-19. Vaccines 2021; 9: 1-16. doi:10.3390/vaccines9010015

[97] Paddon C], Westfall PJ, Pitera DJ, Benjamin K, Fisher K, McPhee D, Leavell MD, Tai A, Main A, Eng D, Polichuk DR, Teoh KH, Reed DW, Treynor T, Lenihan J, Fleck M, Bajad S, Dang G, Dengrove D, Diola D, Dorin G, Ellens KW, Fickes S, Galazzo J, Gaucher SP, Geistlinger T, Henry R, Hepp M, Horning $T$, lqbal T, jiang $H$, Kizer L, Lieu B, Melis D, Moss N, Regentin R, Secrest S, Tsuruta H, Vazquez R, Westblade LF, Xu L, Yu M, Zhang Y, Zhao L, Lievense J, Covello PS, Keasling JD, Reiling KK, Renninger NS, Newman JD. High-level semisynthetic production of the potent antimalarial artemisinin. Nature 2013; 496: 528-532. doi:10.1038/nature12051

[98] Fox JL. First plant-made biologic approved. Nat Biotechnol 2012; 30: 472. doi:10.1038/nbt0612-472 
[99] Shaaltiel Y, Bartfeld D, Hashmueli S, Baum G, Brill-Almon E, Galili G, Dym O, Boldin-Adamsky SA, Silman I, Sussman JL, Futerman AH, Aviezer D. Production of glucocerebrosidase with terminal mannose glycans for enzyme replacement therapy of Gaucher's disease using a plant cell system. Plant Biotechnol J 2007; 5: 579-590. doi:10.1111/ j.1467-7652.2007.00263.x

[100] Zimran A, Wajnrajch M, Hernandez B, Pastores GM. Taliglucerase alfa: Safety and efficacy across 6 clinical studies in adults and children with Gaucher disease. Orphanet J Rare Dis 2018; 13: 36. doi:10.1186/ s13023-018-0776-8

[101] Schiermeyer A. Optimizing product quality in molecular farming. Curr Opin Biotechnol 2020; 61: 15-20. doi:10.1016/j.copbio.2019.08.012

[102] Wilding KM, Schinn SM, Long EA, Bundy BC. The emerging impact of cell-free chemical biosynthesis. Curr Opin Biotechnol 2018; 53: 115121. doi:10.1016/j.copbio.2017.12.019

[103] Stech M, Merk H, Schenk JA, Stöcklein WF, Wüstenhagen DA, Micheel B, Duschl C, Bier FF, Kubick S. Production of functional antibody fragments in a vesicle-based eukaryotic cell-free translation system. J Biotechnol 2012; 164: 220-231. doi:10.1016/j.jbiotec.2012.08.020

[104] Schinn SM, Broadbent A, Bradley WT, Bundy BC. Protein synthesis directly from PCR: Progress and applications of cell-free protein synthesis with linear DNA. N Biotechnol 2016; 33: 480-487. doi:10.1016/j. nbt.2016.04.002

[105] Jiang L, Zhao J, Lian J, Xu Z. Cell-free protein synthesis enabled rapid prototyping for metabolic engineering and synthetic biology. Synth Syst Biotechnol 2018; 3: 90-96. doi:10.1016/j.synbio.2018.02.003

[106] Fischer R, Vasilev N, Twyman RM, Schillberg S. High-value products from plants: The challenges of process optimization. Curr Opin Biotechnol 2015; 32: 156-162. doi:10.1016/j.copbio.2014.12.018

[107] Vasilev N, Grömping U, Lipperts A, Raven N, Fischer R, Schillberg S. Optimization of BY-2 cell suspension culture medium for the production of a human antibody using a combination of fractional factorial designs and the response surface method. Plant Biotechnol J 2013; 11: 867-874. doi:10.1111/pbi.12079

[108] Vasilev N, Boccard J, Lang G, Grömping U, Fischer R, Goepfert S, Rudaz S, Schillberg S. Structured plant metabolomics for the simultaneous exploration of multiple factors. Sci Rep 2016; 6: 37390. doi:10.1038/ srep 37390

[109] Covello PS. Making artemisinin. Phytochemistry 2008; 69: 2881-2885. doi:10.1016/j.phytochem.2008.10.001

[110] Turconi ], Griolet F, Guevel R, Oddon G, Villa R, Geatti A, Hvala M, Rossen K, Göller R, Burgard A. Semisynthetic artemisinin, the chemical path to industrial production. Org Process Res Dev 2014; 18: 417-422. doi:10.1021/op4003196

[111] Lim CG, Fowler ZL, Hueller T, Schaffer S, Koffas MA. High-yield resveratrol production in engineered Escherichia coli. Appl Environ Microbiol 2011; 77: 3451-3460. doi:10.1128/AEM.02186-10

[112] Fulzele DP, Heble MR. Large-scale cultivation of Catharanthus roseus cells: Production of ajamalicine in a 20-I airlift bioreactor. J Biotechnol 1994; 35: 1-7. doi:10.1016/0168-1656(94)90185-6

[113] Ramachandra Rao S, Ravishankar GA. Plant cell cultures: chemical factories of secondary metabolites. Biotechnol Adv 2002; 20: 101-153. doi:10.1016/S0734-9750(02)00007-1

[114] Razay G, Wilcock GK. Galantamine in Alzheimer's disease. Expert Rev Neurother 2008; 8: 9-17. doi:10.1586/14737175.8.1.9

[115] Marco-Contelles ], do Carmo Carreiras M, Rodríguez C, Villarroya M, García AG. Synthesis and pharmacology of Galantamine. Chem Rev 2006; 106: 116-133. doi:10.1021/cr040415t

[116] Reichman WE. Current pharmacologic options for patients with Alzheimer's disease. Ann Gen Hosp Psychiatry 2003; 2: 1. doi:10.1186/ 1475-2832-2-1
[117] Chen W, Balan P, Popovich DG. Analysis of ginsenoside content (Panax ginseng) from different regions. Molecules 2019; 24: 29-41. doi:10.3390/molecules24193491

[118] Hansen EH, Møller BL, Kock GR, Bünner CM, Kristensen C, Jensen OR, Okkels FT, Olsen CE, Motawia MS, Hansen J. De novo biosynthesis of vanillin in fission yeast (Schizosaccharomyces pombe) and baker's yeast (Saccharomyces cerevisiae). Appl Environ Microbiol 2009; 75: 27652774. doi:10.1128/AEM.02681-08

[119] Brochado AR, Matos C, Møller BL, Hansen J, Mortensen UH, Patil KR. Improved vanillin production in baker's yeast through in silico design. Microb Cell Fact 2010; 9: 84. doi:10.1186/1475-2859-9-84

[120] Koopman F, Beekwilder J, Crimi B, van Houwelingen A, Hall RD, Bosch D, van Maris AJ, Pronk JT, Daran JM. De novo production of the flavonoid naringenin in engineered Saccharomyces cerevisiae. Microb Cell Fact 2012; 11: 155. doi:10.1186/1475-2859-11-155

[121] Westfall PJ, Pitera DJ, Lenihan JR, Eng D, Woolard FX, Regentin R, Horning T, Tsuruta H, Melis DJ, Owens A, Fickes S, Diola D, Benjamin KR, Keasling JD, Leavell MD, McPhee DJ, Renninger NS, Newman JD, Paddon C.. Production of amorphadiene in yeast, and its conversion to dihydroartemisinic acid, precursor to the antimalarial agent artemisinin. Proc Natl Acad Sci U S A 2012; 109: E1111-1118. doi:10.1073/pnas.1110740109

[122] Paddon C], Westfall PJ, Pitera DJ, Benjamin K, Fisher K, McPhee D, Leavell MD, Tai A, Main A, Eng D, Polichuk DR, Teoh KH, Reed DW, Treynor T, Lenihan J, Fleck M, Bajad S, Dang G, Dengrove D, Diola D, Dorin G, Ellens KW, Fickes S, Galazzo J, Gaucher SP, Geistlinger T, Henry R, Hepp M, Horning T, lqbal T, Jiang H, Kizer L, Lieu B, Melis D, Moss N, Regentin R, Secrest S, Tsuruta H, Vazquez R, Westblade LF, Xu L, Yu M, Zhang Y, Zhao L, Lievense J, Covello PS, Keasling JD, Reiling KK, Renninger NS, Newman JD. High-level semisynthetic production of the potent antimalarial artemisinin. Nature 2013; 496: 528-532. doi:10.1038/nature12051

[123] Mazalovska M, Kouokam JC. Transiently expressed mistletoe lectin II in Nicotiana benthamiana demonstrates anticancer activity in vitro. Molecules 2020; 25: 2562. doi:10.3390/molecules 25112562

[124] Kommineni V, Markert M, Ren Z, Palle S, Carrillo B, Deng J, Tejeda A, Nandi S, McDonald KA, Marcel S, Holtz B. In vivo glycan engineering via the mannosidase I inhibitor (kifunensine) improves efficacy of rituximab manufactured in Nicotiana benthamiana plants. Int J Mol Sci 2019; 20: 194. doi:10.3390/ijms20010194

[125] Brodzik R, Glogowska M, Bandurska K, Okulicz M, Deka D, Ko K, van der Linden J, Leusen JH, Pogrebnyak N, Golovkin M, Steplewski Z, Koprowski $\mathrm{H}$. Plant-derived anti-Lewis Y mAb exhibits biological activities for efficient immunotherapy against human cancer cells. Proc Natl Acad Sci U S A 2006; 103: 8804-8809. doi:10.1073/pnas.0603043103

[126] Hurtado J, Acharya D, Lai H, Sun H, Kallolimath S, Steinkellner H, Bai F, Chen Q. In vitro and in vivo efficacy of anti-chikungunya virus monoclonal antibodies produced in wild-type and glycoengineered Nicotiana benthamiana plants. Plant Biotechnol J 2020; 18: 266-273. doi:10.1111/pbi.13194

[127] Hamorsky KT, Kouokam JC, Jurkiewicz JM, Nelson B, Moore L], Husk AS Kajiura H, Fujiyama K, Matoba N. N-Glycosylation of cholera toxin B subunit in Nicotiana benthamiana: Impacts on host stress response, production yield and vaccine potential. Sci Rep 2015; 5: 8003. doi:10.1038/srep08003

[128] Hamorsky KT, Kouokam JC, Bennett LJ, Baldauf KJ, Kajiura H, Fujiyama $\mathrm{K}$, Matoba N. Rapid and scalable plant-based production of a cholera toxin $B$ subunit variant to aid in mass vaccination against cholera outbreaks. PLoS Negl Trop Dis 2013; 7: e2406. doi:10.1371/journal. pntd.0002046

[129] Dent M, Hurtado J, Paul AM, Sun H, Lai H, Yang M, Esqueda A, Bai F, Steinkellner $\mathrm{H}$, Chen Q. Plant-produced anti-dengue virus monoclonal antibodies exhibit reduced antibody-dependent enhancement of infection activity. J Gen Virol 2016; 97: 3280-3290. doi:10.1099/ jgv.0.000635 
[130] Kim MY, Jang YS, Yang MS, Kim TG. High expression of consensus dengue virus envelope glycoprotein domain III using a viral expression system in tobacco. Plant Cell Tissue Organ Cult 2015; 122: 445-451. doi:10.1007/s11240-015-0781-8

[131] Diamos AG, Hunter JGL, Pardhe MD, Rosenthal SH, Sun H, Foster BC, DiPalma MP, Chen Q, Mason HS. High level production of monoclonal antibodies using an optimized plant expression system. Front Bioeng Biotechnol 2020; 7: 472. doi:10.3389/fbioe.2019.00472

[132] Jez J, Castilho A, Grass J, Vorauer-Uhl K, Sterovsky T, Altmann F, Steinkellner $\mathrm{H}$. Expression of functionally active sialylated human erythropoietin in plants. Biotechnol J 2013; 8: 371-382. doi:10.1002/biot. 201200363

[133] Kytidou K, Beenakker TJM, Westerhof LB, Hokke CH, Moolenaar GF, Goosen N, Mirzaian M, Ferraz MJ, de Geus M, Kallemeijn WW, Overkleeft HS, Boot RG, Schots A, Bosch D, Aerts JMFG. Human alpha galactosidases transiently produced in Nicotiana benthamiana leaves: New insights in substrate specificities with relevance for Fabry disease. Front Plant Sci 2017; 8: 1026. doi:10.3389/fpls.2017.01026

[134] D’Aoust MA, Lavoie PO, Couture MM, Trépanier S, Guay JM, Dargis M, Mongrand S, Landry N, Ward BJ, Vézina LP. Influenza virus-like particles produced by transient expression in Nicotiana benthamiana induce a protective immune response against a lethal viral challenge in mice. Plant Biotechnol J 2008; 6: 930-940. doi:10.1111/j.14677652.2008.00384.x

[135] Kanagarajan S, Tolf C, Lundgren A, Waldenström J, Brodelius PE. Transient expression of hemagglutinin antigen from low pathogenic avian influenza a (H7N7) in Nicotiana benthamiana. PLoS One 2012; 7: e33010. doi:10.1371/journal.pone.0033010

[136] Huang Z, LePore K, Elkin G, Thanavala Y, Mason H. High yield rapid production of hepatitis $B$ surface antigen in plant leaf by a viral expression system. Plant Biotechnol J 2008; 6: 202-209. doi:10.1111/j.14677652.2007.00316.x

[137] Pyrski M, Mieloch AA, Plewiński A, Basińska-Barczak A, Gryciuk A, Bociąg P, Murias M, Rybka JD, Pniewski T. Parenteral-oral immunization with plant-derived HBCAG as a potential therapeutic vaccine against chronic hepatitis B. Vaccines (Basel) 2019; 7: 211. doi:10.3390/vaccines7040211

[138] Hanittinan O, Oo Y, Chaotham C, Rattanapisit K, Shanmugaraj B, Phoolcharoen W. Expression optimization, purification and in vitro characterization of human epidermal growth factor produced in Nicotiana benthamiana. Biotechnol Reports 2020; 28: e00524. doi:10.1016/j.btre.2020.e00524

[139] Margolin E, Chapman R, Meyers AE, van Diepen MT, Ximba P, Hermanus T, Crowther C, Weber B, Morris L, Williamson AL, Rybicki EP. Production and immunogenicity of soluble plant-produced HIV-1 subtype C envelope gp140 immunogens. Front Plant Sci 2019; 10: 1378. doi:10.3389/fpls.2019.01378

[140] Seber Kasinger LE, Dent MW, Mahajan G, Hamorsky KT, Matoba N. A novel anti-HIV-1 bispecific bNAb-lectin fusion protein engineered in a plant-based transient expression system. Plant Biotechnol J 2019; 17 : 1646-1656. doi:10.1111/pbi.13090

[141] Singh AA, Pooe O, Kwezi L, Lotter-Stark T, Stoychev SH, Alexandra K, Gerber I, Bhiman JN, Vorster J, Pauly M, Zeitlin L, Whaley K, Mach L, Steinkellner H, Morris L, Tsekoa TL, Chikwamba R. Plant-based production of highly potent anti-HIV antibodies with engineered posttranslational modifications. Sci Rep 2020; 10: 62101. doi:10.1038/s41598020-63052-1
[142] Voepel N, Boes A, Edgue G, Beiss V, Kapelski S, Reimann A, Schillberg S, Pradel G, Fendel R, Scheuermayer M, Spiegel H, Fischer R. Malaria vaccine candidate antigen targeting the pre-erythrocytic stage of Plasmodium falciparum produced at high level in plants. Biotechnol J 2014; 9: 1435-1445. doi:10.1002/biot.201400350

[143] Tsekoa TL, Lotter-Stark T, Buthelezi S, Chakauya E, Stoychev SH, Sabeta C, Shumba W, Phahladira B, Hume S, Morton J, Rupprecht CE, Steinkellner H, Pauly M, Zeitlin L, Whaley K, Chikwamba R. Efficient in vitro and in vivo activity of glyco-engineered plant-produced rabies monoclonal antibodies E559 and 62-71-3. PLoS One 2016; 11: e0159313. doi:10.1371/journal.pone.0159313

[144] Shanmugaraj B, Rattanapisit K, Manopwisedjaroen S, Thitithanyanont A, Phoolcharoen W. Monoclonal antibodies B38 and H4 produced in Nicotiana benthamiana neutralize SARS-CoV-2 in vitro. Front Plant Sci 2020; 11: 589995. doi:10.3389/fpls.2020.589995

[145] Siriwattananon K, Manopwisedjaroen S, Kanjanasirirat P, Budi Purwono P, Rattanapisit K, Shanmugaraj B, Smith DR, Borwornpinyo S, Thitithanyanont A, Phoolcharoen W. Development of plant-produced recombinant ACE2-Fc fusion protein as a potential therapeutic agent against SARS-CoV-2. Front Plant Sci 2021; 11: 604663. doi:10.3389/ fpls.2020.604663

[146] Castilho A, Schwestka J, Kienzl NF, Vavra U, Grünwald-Gruber C, Izadi S, Hiremath C, Niederhöfer J, Laurent E, Monteil V, Mirazimi A, Wirnsberger G, Stadlmann J, Stöger E, Mach L. Strasser R. Generation of enzymatically competent SARS-CoV-2 decoy receptor ACE2-Fc in glycoengineered Nicotiana benthamiana. Biotechnol J 2021; 16: e2000566. doi:10.1002/biot.202000566

[147] Rattanapisit K, Shanmugaraj B, Manopwisedjaroen S, Purwono PB, Siriwattananon K, Khorattanakulchai N, Hanittinan O, Boonyayothin W, Thitithanyanont A, Smith DR, Phoolcharoen W. Rapid production of SARS-CoV-2 receptor binding domain (RBD) and spike specific monoclonal antibody CR3022 in Nicotiana benthamiana. Sci Rep 2020; 10: 17698. doi:10.1038/s41598-020-74904-1

[148] Lai H, He J, Hurtado J, Stahnke J, Fuchs A, Mehlhop E, Gorlatov S, Loos A, Diamond MS, Chen Q. Structural and functional characterization of an anti-West Nile virus monoclonal antibody and its single-chain variant produced in glycoengineered plants. Plant Biotechnol J 2014; 12 : 1098-1107. doi:10.1111/pbi. 12217

[149] He J, Peng L, Lai H, Hurtado J, Stahnke J, Chen Q. A plant-produced antigen elicits potent immune responses against West Nile Virus in mice. Biomed Res Int 2014; 2014: 952865. doi:10.1155/2014/952865

[150] He J, Lai H, Esqueda A, Chen Q. Plant-produced antigen displaying virus-like particles evokes potent antibody responses against West Nile virus in mice. Vaccines 2021; 9: 1-13. doi:10.3390/vaccines9010060

[151] Jugler C, Joensuu J, Chen Q. Hydrophobin-protein a fusion protein produced in plants efficiently purified an anti-West Nile Virus monoclonal antibody from plant extracts via aqueous two-phase separation. Int J Mol Sci 2020; 21: 2140. doi:10.3390/ijms21062140

[152] Diamos AG, Pardhe MD, Sun H, Hunter JGL, Kilbourne J, Chen Q, Mason HS. A highly expressing, soluble, and stable plant-made IgG fusion vaccine strategy enhances antigen immunogenicity in mice without adjuvant. Front Immunol 2020; 11: 1: 576012. doi:10.3389/fimmu. 2020.576012

[153] Yang M, Sun H, Lai H, Hurtado J, Chen Q. Plant-produced Zika virus envelope protein elicits neutralizing immune responses that correlate with protective immunity against Zika virus in mice. Plant Biotechnol ] 2018; 16: 572-580. doi:10.1111/pbi.12796 